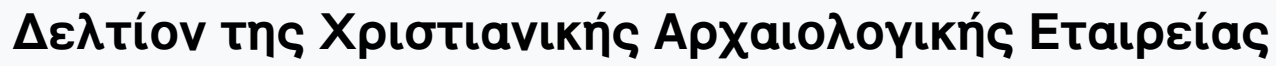

Tó 15 (1991)

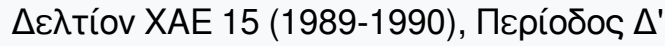

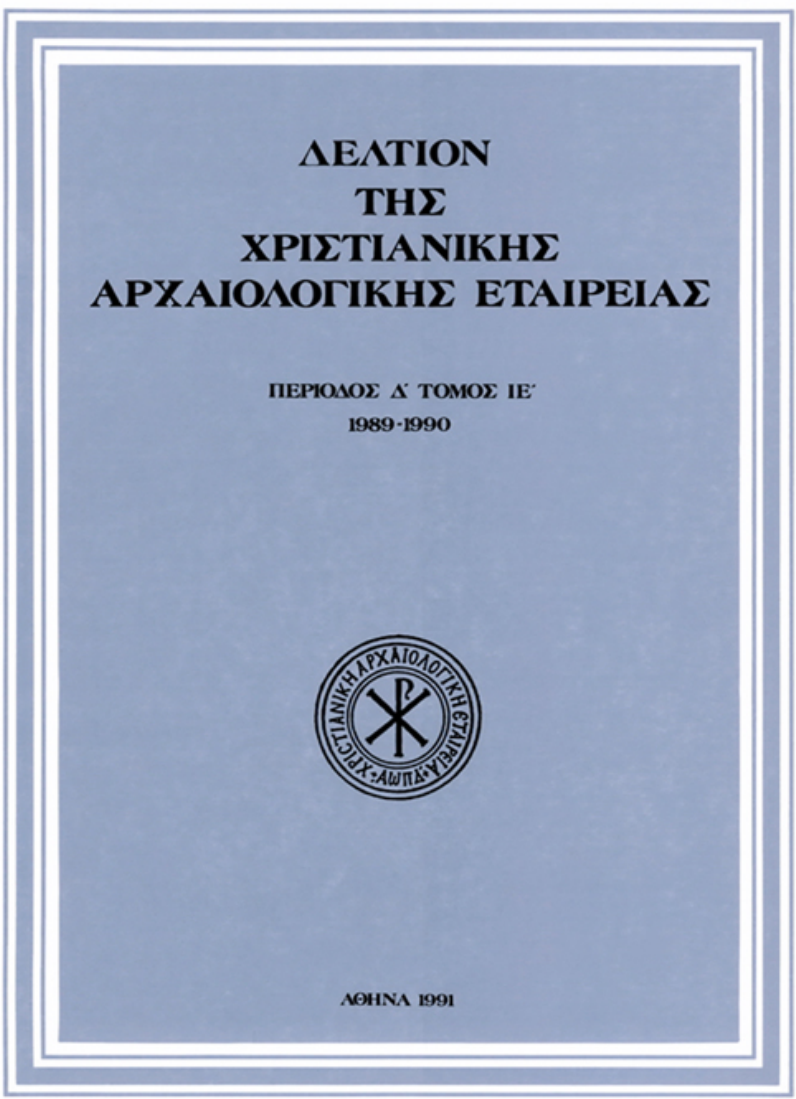

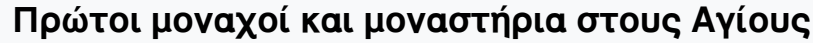
Tónous

Vassilios TZAFERIS

doi: $10.12681 /$ dchae.1034

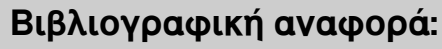

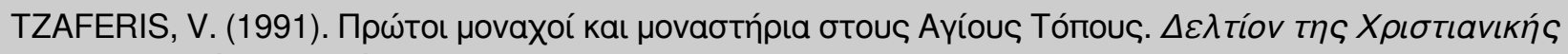
Архаıолоүєки́s Eтаıрві́as, 15, 43-66. https://doi.org/10.12681/dchae.1034 


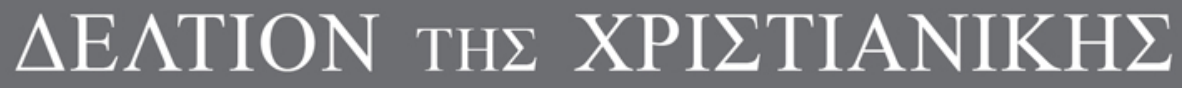 APXAIO $\Lambda$ OГIKH $\Sigma$ ETAIPEIA $\Sigma$}

Early Monks and Monasteries in the Holyland

Vassilios TZAFERIS

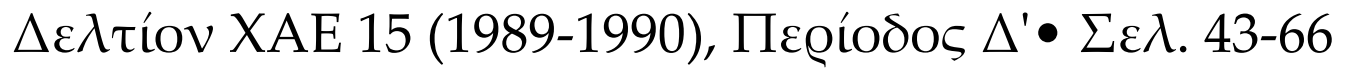
A@HNA 1991 


\title{
Vassilios Tzaferis
}

\section{EARLY MONKS AND MONASTERIES IN THE HOLYLAND}

\author{
To Manolis Chatzidakis
}

$\mathrm{U}$ ntil three decades ago our knowledge on the monks and monasteries in the Holyland during the Early Christian periods, the 4 th to early 7 th centuries A.D., came, almost exclusively, from monastic and ecclesiastic sources. The first, mainly biographies, sketch out the lives of prominent individual monks, exalt their spirituality and praise the high standard of sacredness the monks strived to attain in the desert through spiritual asceticism or bodily exercise. Here and there the biographers also hand down valuable information concerning the mundane aspects of the monachism, such as the internal organisation of the monastery, the various professions monks were called to practice, their daily diet, etc. However, the deliberate aim of the biographer was not to give a precise description of the outer and worldly expression of monastic life but to "inform the reader about the edifying attainments of the holy fathers", as John Moschos puts it in his Leimon". The ecclesiastical sources, on the other hand, dealt with the subject in general terms neither entering into the peculiarity of the individual monk, nor into the architectural or functional framework within which early Christian monachism emerged and developed. The purpose of the present paper is not to deal with or analyse any of the above literary sources, but to make known to the public a third source, namely, the archaeological discoveries and investigations, which in the years have brought to light valuable new material on the subject. In contrast to the literary sources just mentioned, which describe the spiritual sphere of the early monks, their struggles against desires of the flesh and their metacosmic expectations, the archaeological sources elucidate the physical and geographical environment of the monastic movement, the desperate fight of the monks for survival, as individuals and as members of a congregation with the physical and mundane adversities and their anguish in trying to create for themselves a better society.

It is amazing how rich and diverse the archaeological remains are, both in architectural ruins and in everyday utensils which were left behind by a community of people whose initial aims were, at first appearance, the avoidance of the secular world and the accomplishment of absolute indigence. Systematic archaeological investigation, which began some thirty years ago now covers almost the entire region of the Judean wilderness, southern Sinai, the valley of Jericho and the southern part of the plain of Jordan. In these areas, in which most of the monastic activities of the 4th to early 7 th centuries were concentrated, were surveyed, or partly excavated, more than one hundred and fifty monastic units representing all the monastic orders and formations practiced in the Holyland. This number does not include the hundreds of natural caves and clefts used as hermitages found along the cliffs of the numerous desert gorges. In the Judean Desert alone were identified more than sixty monasteries (Fig. 1) fifteen additional monasteries were found in the narrow strip of the plain that lies between Jericho and the Jordan river, while many others are still lying covered by the soil ${ }^{2}$.

Strenuous work has been done, also, in southern Sinai in the regions around St. Catherine's monastery and in Wadi Firan. Here the archaeological surveys and inves-

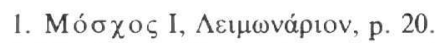

2. The first studies on the monasteries of the Holyland were written in the final decades of the last century. The pioneering works of Karl Marti (Mittheilungen von Baurath C. Schick in Jerusalem über die alten Lauras und Kloster in der Wuste Juda, in Zeitschrift des Deutschen Palestinavereins 3 (1880), pp. 1-47) and Simeon Vailhe, who for the first time composed an alphabetical catalogue of the monasteries, were based on the literary sources and surface archaeological ruins. These studies were followed, in the beginning of this century by sever-

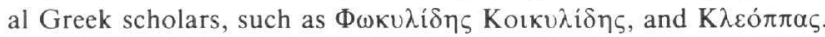
The latter, translated into Greek the catalogue of S. Vailhe adding a considerable number of new and previously unknown monasteries.

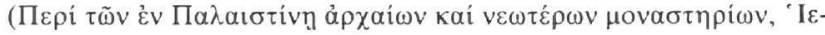

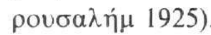

In the sixties a new era in the study of the monasteries began with the discovery of many of sites in which were undertaken archaeological excavations (see Corbo, Chitty and P. Bar-Adon). However, systematic study only started in the seventies with the inauguration of a general archaeological survey undertaken by the Israel Department of Antiquities and Museums, the purpose of which was to survey the whole of the Holyland and record all the archaeological sites. Part of the results of these surveys have already appeared, while others will soon be published (see Rubin, Hirschfeld, and others). 


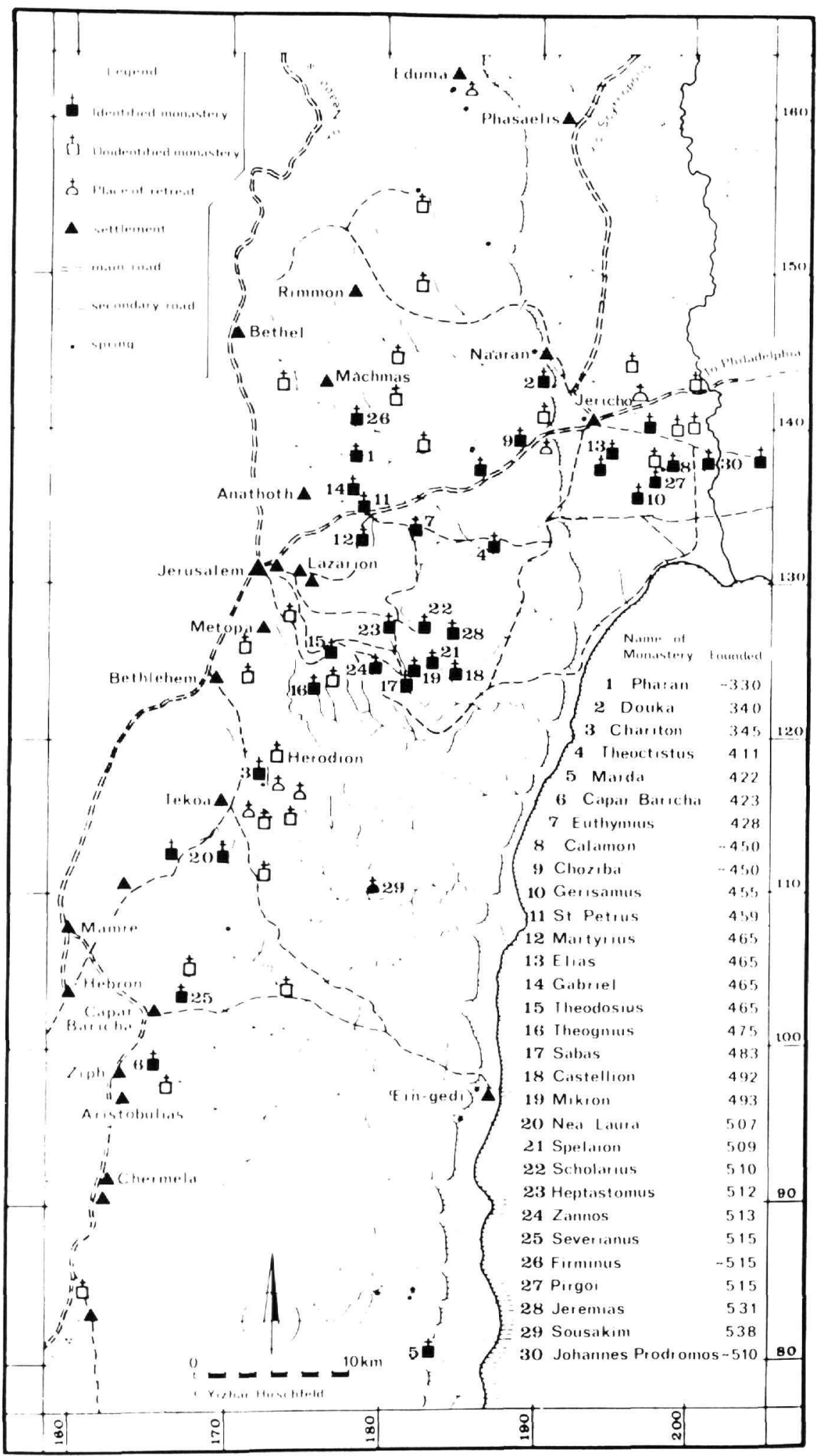

Fig. 1. Map of the Judean Desert showing the location of Early Christian Monasteries. (Courtesy of I. Hirschfeld). 
tigations shed new light on monastic ways of life during the Early Christian period ${ }^{3}$.

In addition, many monasteries were excavated in other parts of the Holyland, such as, in the region of Negev, along the western coast of Palestine, in the urban areas of Jerusalem, Bethlehem, Skythopolis (Beth-Shean), around the Lake of Tiberias and as far as in the area of Ptolemais-Acco in the north-western Galilee (Fig. 1). Added together the monasteries found as yet in the Holyland, both in surveys and excavations, reach impressive numbers. To these, if we add the numerous others mentioned in literary sources and yet not identified, then the final estimate may reach several hundreds. The existence of such an enormous number of monasteries is astounding taking into consideration the geographic limits of the country on one hand and the hard topographic and climatic conditions prevailing in most of the regions in which the majority of the monasteries were established, on the other.

On the basis of the archaeological evidence, we are now able to sketch out the course of the establishment and evolution of the monastic movement in the Holyland, the areas selected for monastic solitude, the methods the monks used to confront and overcome the physical and climatic hardships and to secure their necessary livelihood, the architectural forms preferred and the ways the monks lived as individuals or as part of the community. It is noteworthy, that neither the establishment nor the evolution of the monastic movement in the Holyland were of a pioneering character. Its conceptual development as well as its inner organisation and external appearance, were, to a great extent, based on the achievements of the Egyptian and Cappadocian monastic models. However, from the beginning, Holyland monachism followed a distinctive line of its own, due, first, to the peculiar urges of those who came into the movement and secondly, to the special circumstances under which the movement was established on the soil of the Holyland.

If we exempt the first uninstitutionalised introduction of monachism into the region of Gaza by St. Hilarion, in the first half of the 4th century, which undoubtedly constituted a branch of the Egyptian movement far off its centre, the establishment of monachism on the soil of the Holyland, in the second half of the 4th century, had its own roots and its own conceptual ideology. A look on the map of the monasteries will explain it clearly. The vast majority of them are concentrated in three areas; southern Sinai, around the Sea of Galilee and the Judean Desert.

Obviously, the early Christian monks did not prefer these places as being the most suitable for settlement in

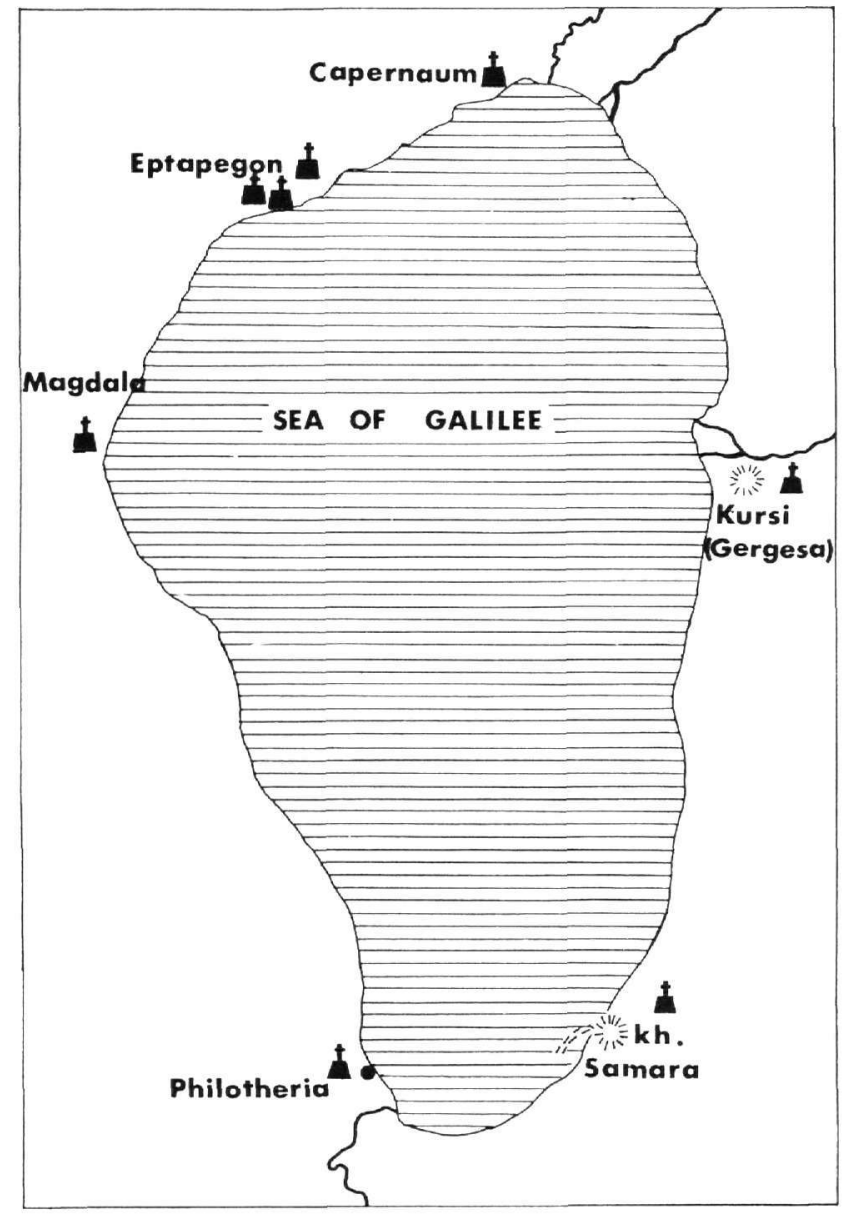

Fig. 2. Map of the Sea of Galilee showing the Early Christian Monasteries so far discovered around its coasts.

terms of their topography and climate (even though some of the places, as we will see below, did indeed respond to the requirements of solitary settlement), but mainly because they were strongly connected to the events and happenings of the Bible. Thus, the monastic life in the desert of Sinai, from the beginning was gathered around the sites associated with the experiences of Moses and the children of Israel. The monastery of St. Catherine, built on the site of the 'Burning Bush' from which the Lord had spoken to Moses, was actually, at the centre of Sinaitic early monachism and one of the most important monasteries there, though not the only one. Today, thanks to archaeological surveys and

3. Archaeological studies on the monasticism of southern Sinai, outside the monastery of St. Catherine's, which included surveys and excavations, started only after the Six-Day War in 1967 when all of the region was opened to scholars and communications were possible. The results of these studies are not yet published. I am grateful to A. Goren for the information given to me orally. 


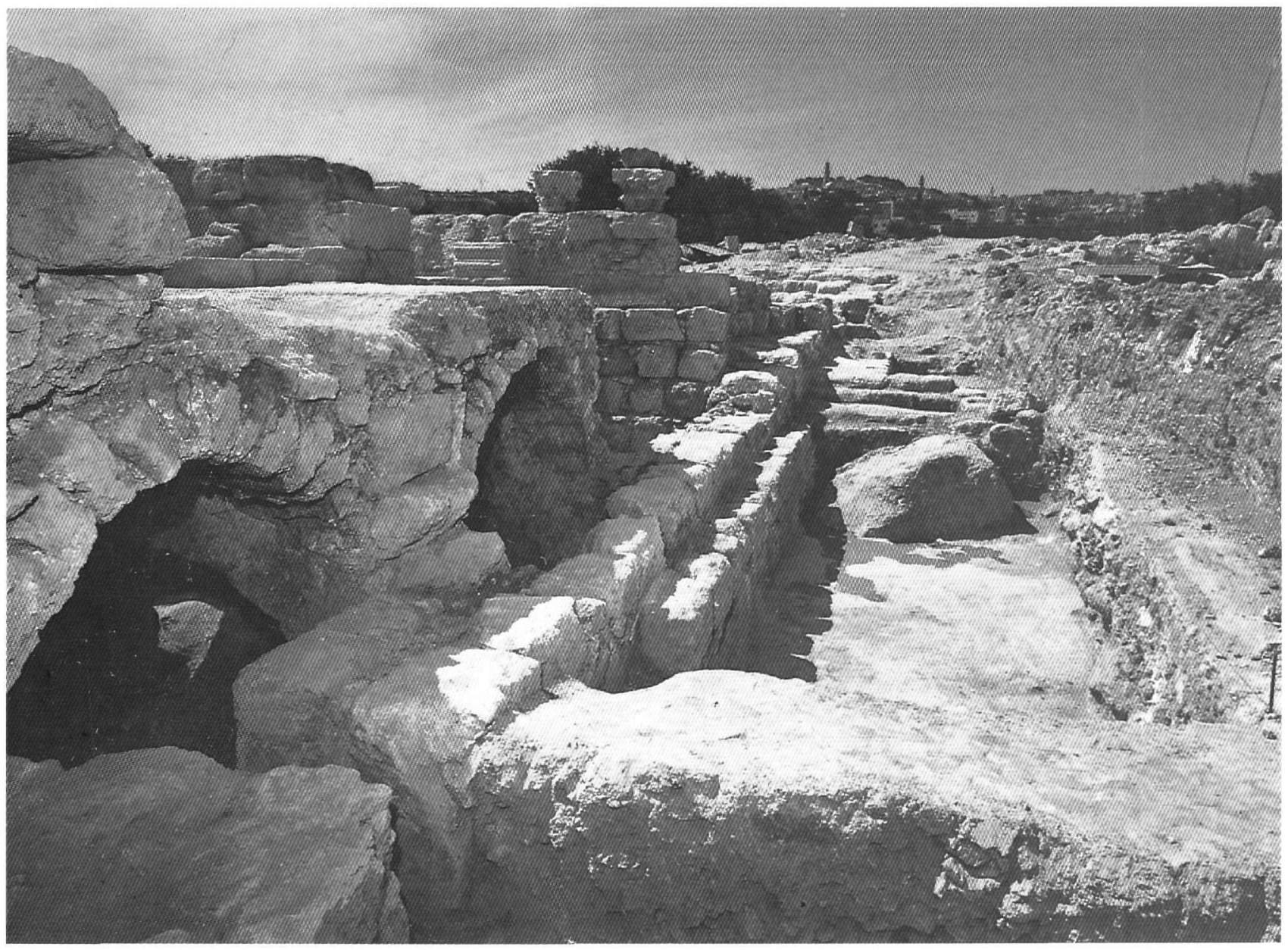

Fig. 3. Remains of the Monastery at Shepherd's Fields east of Bethlehem. The Monastery was built on a Holy Site related to the events of Jesus' birth. (Luke 2: 8-12).

investigations we know that numerous other monasteries and monastic settlements of various sorts were found, during the 4 th to early 7 th centuries, at other sites connected with the stories of the Exodus and of the wanderings of the twelve tribes of Israel. Similarly, the monasteries found around the Sea of Galilee were, mostly, located on the very sites associated with Jesus's life, ministry and apostles (Fig. 2). Places, such as Magdala, the birth place of Maria Magdalene, Eptapegon, the site of the multiplication of the fishes and loaves and Gergessa on the eastern coast of the lake, where the "swine miracle" occurred, had become during the 5th to 7 th centuries A.D., not only much frequented stations for Christian pilgrimages but also, important monastic centres (Figs 3-4). Massive monastic settlement extended, most likely, as far as Mount Tabor and to the town of Nazareth.

Judea, with its numerous holy places associated with the events and holy persons of both the Old and the New Testaments, was especially attractive to monks and it was here that the majority of monastic life was centred. All Judea, from the coastal plain in the west to the Jordan valley and the Dead Sea in the east, was looked upon as proper land for settling. However, JerusalemBethlehem and their surroundings, the plain of Jericho and the southern part of the Jordan valley and the strip along the desert margin were considered the most preferable. The exclusiveness of Jerusalem, Bethlehem, Jericho and the Jordan River in the Christian faith, as being the places where most of the events of the New Testament occurred, was obviously, the main reason for massive monastic settlement (Fig. 1). On the other hand, the Judean Desert combined, both, religious importance, as being associated with many narratives of the Old Testament, and suitable places for solitary living. The geographical and topographical nature of the desert, split 


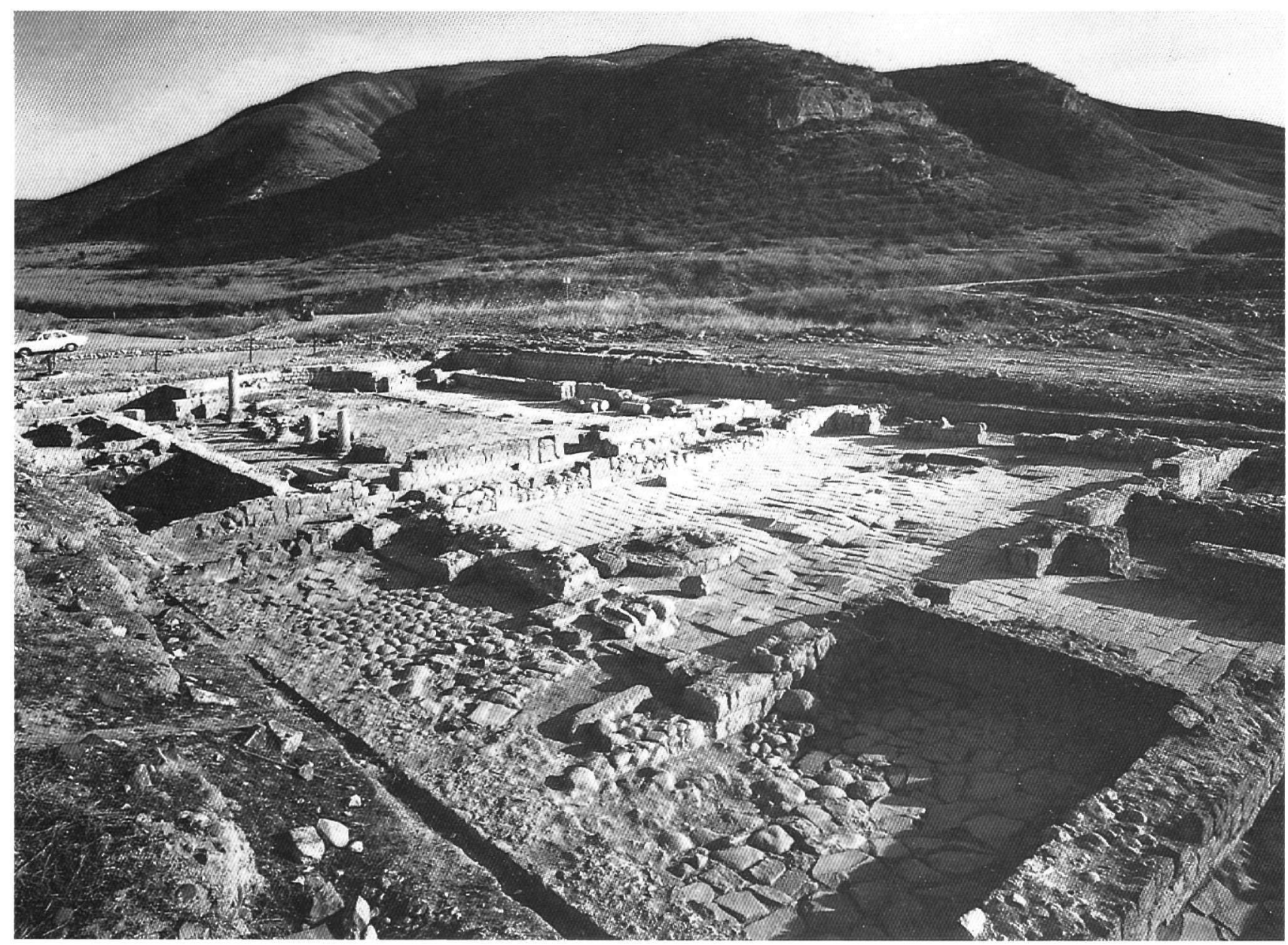

Fig. 4. The Monastery discovered at Kursi on the eastern coast of the Sea of Galilee, built on a Holy Site connected with the "Swine Miracle". (Luke 8: 26-39).

as it is into various ravines and canyons with numerous caves, provided the best natural cover for the monks. Besides, its bearable and comfortable climate, with its perennial water sources and its relatively frequent rainfalls, meant that the Judean Desert constituted the ideal place for organised monastic habitation. In addition, it provided, wasteland and desolated wildernesses, especially in its south-east part, where monks and ascetics could, from time to time, retreat and live in almost absolute isolation. The map of the monasteries in the Judean Desert, proves beyond doubt, that monastic habitation, with very few exceptions, was limited to areas close to urban centres or in such desolated regions where living conditions were, if not comfortable, at least bearable.

As a general remark on early monachism of the Holyland, one can say, that neither the archaeological discoveries nor the literary sources reveal ascetic extremes, both, in behaviour and in the way of living. Such a tranquil monachism was obviously inspired by spiritual urges, ambitions and aims quite different from those which created, a little earlier than the 4th century, the extolled monastic movement in Egypt.

The foundation of the monasteries at holy locations or at venerated places of pilgrimage, excluded, from the start, the possibility of absolute isolation and compelled the monks, unwillingly, to harness themselves into the duties of host and hospitality. As a matter of fact, the literary sources confirm that the majority of the monasteries of the Holyland, were involved, in some way or the other, with the Christian pilgrimage enterprise in all its aspects ${ }^{4}$. Consequently, the entire mechanism of the

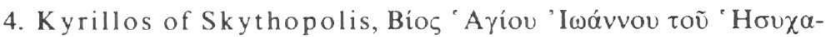

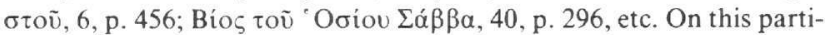
cular subject see: D. Savramis, Soziologie des byzantinischen Monchtums, Leiden 1962. 

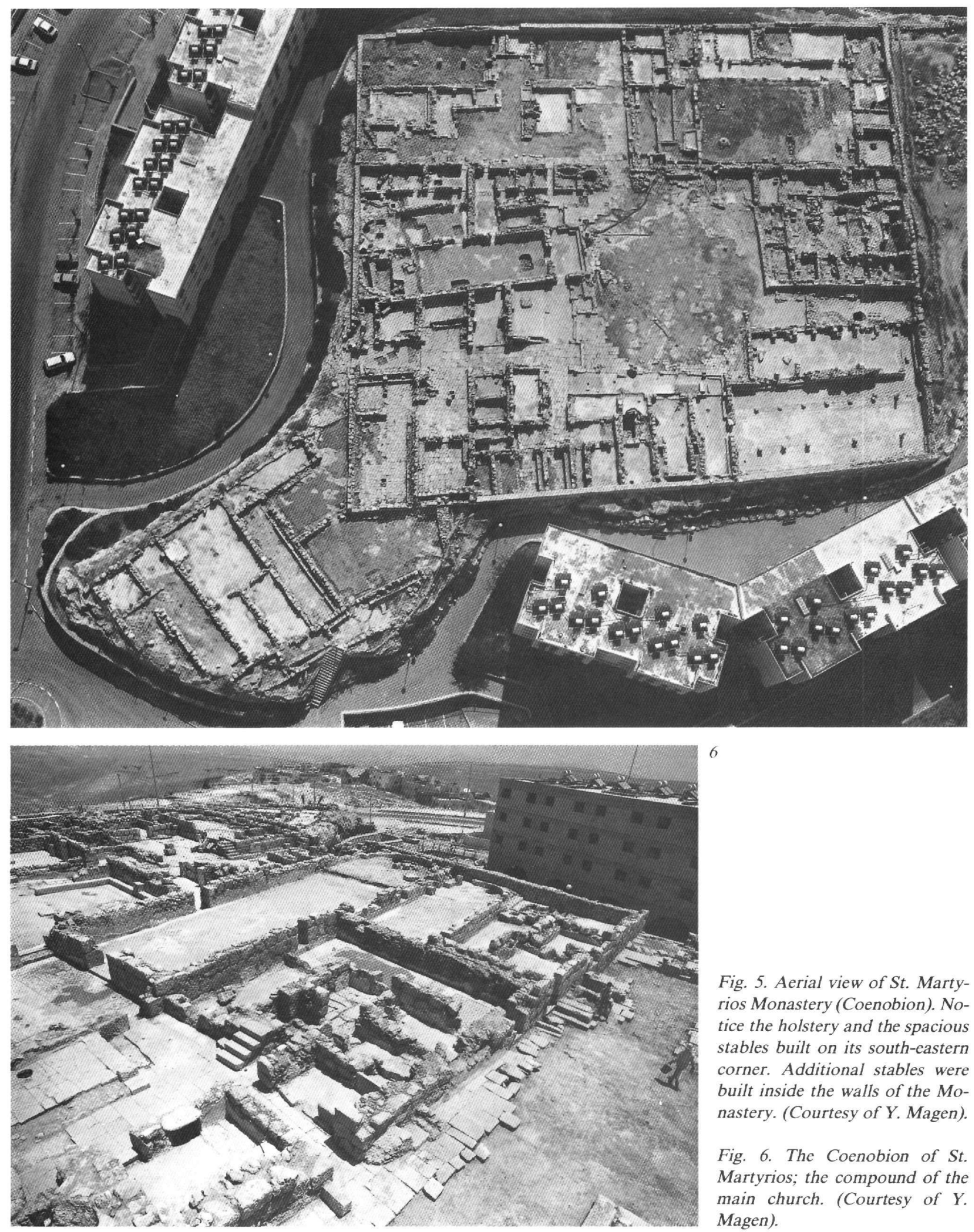

Fig. 5. Aerial view of St. Martyrios Monastery (Coenobion). Notice the holstery and the spacious stables built on its south-eastern corner. Additional stables were built inside the walls of the Monastery. (Courtesy of Y. Magen).

Fig. 6. The Coenobion of St. Martyrios; the compound of the main church. (Courtesy of $Y$. Magen). 
monastery, its inner organisation, its planning and even its location were subjected, to a great degree, to the demands of this activity rather than to the reasoning of ascetic ideology.

The archaeological evidence clearly proves, that almost all the early monasteries in the Holyland were founded along communication arteries or very close to them. This phenomenon is more conspicuous in the Judean Desert where the monasteries were concentrated along roads, tracks or across the ravines, the beds of which provided throughout history congenial routes for all kinds of transportation. For instance, the strip of the main road connecting the two important Christian pilgrimages centres of Jericho and Jerusalem, had already in the early 5th century, attracted the attention of the monks. On both sides of this route were established some of the most densely populated monasteries may of them also recognised as holy-sites.

Similar crowded monasteries of various orders were also founded along the main road linking Jerusalem to Bethlehem and on the northern bank of the Dead Sea. Here again some of them were placed at holy locations. Another main public road, which crossed the desert from Jerusalem through Bethlehem, Hebron to EinGedi on the western bank of the Dead Sea also become a centre of dense monastic settlement. Also all the monasteries of the Jordan and Jericho valley, most of which were situated at holy places, were joined to the road system crossing the valley from north to south and from east to west. The same axiom was in force for those monastic centres built along the coast of the Sea of Galilee. Here, the monasteries were not only bound to the main land road, but also to the water routes connecting all the main holy places found around the lake. The monasteries of Sinai too were, in some way or the other, connected with the main roads used there.

Undoubtedly, the location of the monasteries on the road system of the country was made intentionally. First, it insured convenient intercourse with the urban centres upon which depended the multiple physical needs of the monks and monasteries, and secondly it facilitated the approach of the Christian pilgrimage masses which constituted a considerable source of income. The archaeological discoveries make it very clear that the monks not only directed the pilgrims to their monasteries but that also put great effort in providing them with the necessary facilities for a convenient stay. Spacious and comfortable hostelries, built within the monasteries or adjacent to them, were one of the most characteristic components of the early Palestinian lauras and coenobia. The hostelry of the coenobia of Martyrios (Fig. 5) (see description below), recently discov- ered on the main Jerusalem-Jericho road, is obviously the best example of such a xenodocheion maintained by the monks. It was built outside the walls of the monastery and consisted of three departments, each one having a different function: the church, set aside for the prayer needs of the guests, the living-quarters and the stables (Fig. 6) ${ }^{5}$. Similar hostelries, built separately from the main compound of the monastery were found in the laura of St. Euthymios and in the coenobion of St. Theodosios, both in the north-western part of the Judean Desert.

In the monastery discovered at Kursi, on the eastern bank of the Sea of Galilee, the hostelry was within its walls. It consisted of large buildings, set on the northern wing of the monastery, with spacious living rooms and other facilities for the comfort of the guests. Next to the main entrance of the monastery, inside the walls, was discovered a large two storey building, the lower storey of which served very probably as a divan where the pilgrims and other guests could rest for a while and refresh themselves before they were driven to the church of the monastery or to the chapel of the miracle, built on the slope of an adjacent hill. In front of the main church of the monastery or to the chapel of the miracle, built on the slope of an adjacent hill. In front of the main church stood a spacious open courtyard, where the guests could meet or stroll in their leisure. In times of boredom they could sit on the ground and play different games, such as draughts (checkers), scratched on the slabs of the pavement ${ }^{6}$.

As already stated, many of the monasteries maintained well organised stables for horses, mules and donkeys which they used not only for the transportation of food and other necessities but also for the transfer of the pilgrims and visitors from place to place. The large coenobion of Martyrios, already mentioned, maintained two such stables, one inside the walls of the monastery and the other outside, within the area of the hostelry (Fig. 5). In both, there was enough space to pen a considerable number of horses or mules. The beautiful construction of the buildings, which did not differ at all from that of the monastery itself, and the inner arrangement of the spaces providing comfort and maximum care, may prove how important the stables were to the monastery and how much attention the monks paid in keeping and maintaining the entire project. The same monastery of Martyrios also possessed a sizable refectory (Fig. 7), paved with splendid coloured mosaics, which could easily accommodate more than two hundred

5. Y. Magen, St. Martyrios Monastery.

6. V. Tzaferis, Kursi. 


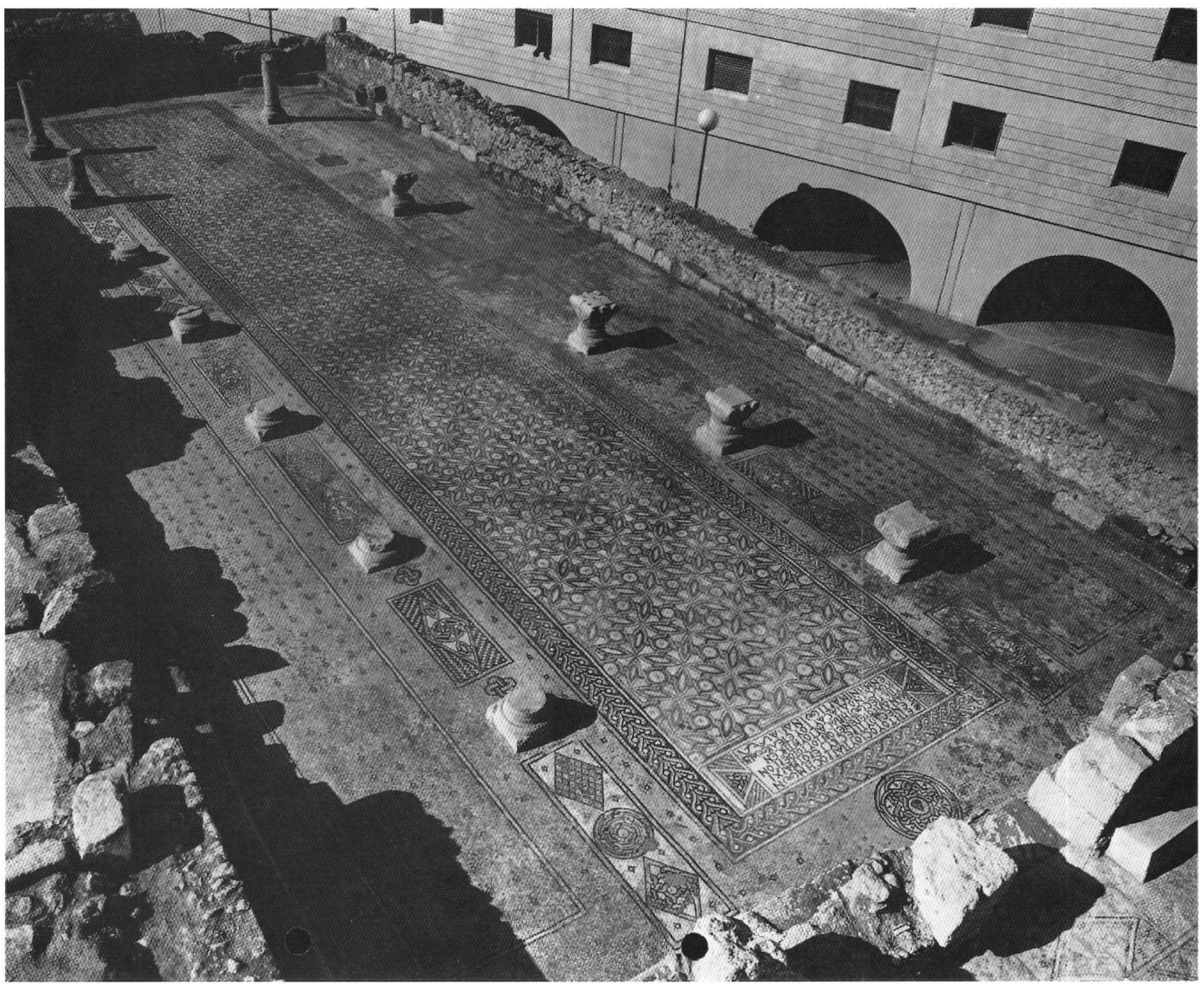

Fig. 7. The Coenobion of St. Martyrios; the refectory and the kitchen units. (Courtesy of Y. Magen).

dinner guests. Undoubtedly, the large and magnificent refectory of the Martyrios monastery gave its services, equally, to the monks and to visitors or transient Christian pilgrims.

The maintenance of hostelries and stables was not the privilege of a few rich monasteries only. Almost, every monastery of any reputation boasted to possess these, that is to say, social establishments the aim of which was to serve the pilgrims and the guests. Hospitality was of primary importance in the ideological conception of early Christian monasticism and monks did not spare effort or means in granting it disinterestedly to everyone. The installation of such social institutions within the monasteries and the efficiency of the monks in maintaining them required proper internal communal organ- isation as well as basic professional knowledge in management. It also demanded long-term logistical policy, a continuous supply of various requirements and above all, an inexhaustible water supply. The archaeological investigations have proved that most of the monasteries of the Holyland possessed all these prerequisites in organisation, professional formation and structural equipment. Both, the lauras and the coenobia are characterised structurally as well planned and well constructed complexes, their external formation reflecting, undoubtedly, a corresponding internally well organised community.

Through archaeology, we now know that the establishment and the construction of many of the monasteries of the Holyland, was the work of provident community 
planners and of ingenious architects or "michanikoi" as the literary sources call them ${ }^{7}$. In no case do we find improvised buildings or plans ill-fitted to the monastic aims they were supposed to fulfil. The topographical placing of the monasteries, their plan and the arrangement of the various basic or subsidiary buildings, within or outside the walls, the courts and gardens, the form and size of the individual cells, as well as the location and plan of the cemeteries were all studied in detail and situated correctly in their right place within the general lay-out of the monastery. Also, the character of the construction reveals the workmanship of highly trained technicians. Undoubtedly, many of them were brought from the near-by towns, though some were monks who knew the builders profession ${ }^{8}$. Equally beautiful is the architectural decoration and the coloured mosaic pavements used in the churches or in the communal spaces of the monastery. The mosaicists ( $\psi \eta \varphi \circ \theta \varepsilon \dot{\varepsilon} \tau \varsigma)$ were artists, mostly employed from outside but some were also monks. The abovementioned structural and artistic perfections do not characterise only the large and the most famous monasteries, but also the small, sometimes unknown, and most remote of monasteries in the Judean Desert. The curious thing is that, if we exclude the very few monasteries built at the expense of the imperial treasury or of the institutional church, all the others were projects of individual initiative. The funding came, mostly, from donations and from the wealth of the monks themselves. The utilisation of most sophisticated monastery plans, taking into consideration all the physical necessities of the monks and the provision of a suitable environment for spiritual and solitary life, reflects, obviously, a balanced community rather than a congregation of abstemious ascetics. This conclusion assumes special significance when the monasteries in question are found in the desert and when the initial aim of their founders was, undoubtedly, abstinence from the social or material world.

Archaeological investigations have brought to light numerous monasteries, which in spite of the fact of being located in the most remote ravines of the Judean Desert, constitute a material micro-society by no means inferior to the societies in town or villages.

One of the best examples of such monasteries is one, yet unidentified, whose ruins were very recently clearer in a small part of Wadi Arugot in the central region of the Judean wilderness (Figs 10-11). The local bedouins named the ruins simply E-Deir, meaning the monastery. The founders of the monastery and the technicians and builders who constructed it, exploited in an optimum way the topography of the place, assembling the various buildings in the right place and in accordance with their function. Thus, across the cliff and attacked to it was built the constant nucleus of the monastery, which consisted of the church, the burial chamber or cave, the refectory and kitchen, the bakery, the storerooms and all the other auxiliary spaces used by the community. All these were arranged in two groups, in the first were assembled those of religious character, while in the second those used for daily activities. The living quarters were put on the sides of the ravine just above the lower cliff. Outside the monastery, along the even parts of the slopes were arranged terraces for cultivation. Here, were the gardens of the monastery in which the monks grew seasonal vegetables for their daily needs.

Special attention was given to the water supply. Here, the designers of the monastery took care to collect every possible drop of water using different techniques and exploiting the topographical location of the monastery. Firstly, they collected all the rain water from the roofs by using pottery pipes built in the walls. The pipes drained the water into larger stone-built conduits, which in their turn, after collecting the surplus rainwater from the open courtyards led it into underground cisterns. Secondly, by using channels, partly cut into the rock and partly built, the collected as much rain water from the surroundings of the monastery as possible. The water was drained into a large reservoir dug on the lower slope of the ravine, outside the monastery. The third device used to increase the water reserves was even more ingenious. In the inner part of the gorge was built a retaining dam creating a spacious open cistern, $15 \times 11$ meters and 2 meters deep. In this way it was possible to collect the flood waters of the ravine. The cistern could supply 330 cubic meters of water to irrigate the gardens of the monastery. Assuming that all the reservoirs were filled up, the monastery would have a regular water supply, both for drinking and irrigation.

The compactness of the plan of the monastery as well as the high standard of the ashlar masonry, point to a well designed building set up, undoubtedly, by experienced architects and designers. Similar attention was also paid to its inner appearance and decoration. The church, the chapel, all the communal rooms and spaces and almost all the cells for the individual monks, were paved with coloured mosaics. The stay in the monastery was very comfortable and quite pleasant.

The lauras were treated in a similar way. Here living was usually based not on communal cohabitation but rather

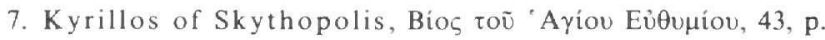
146.

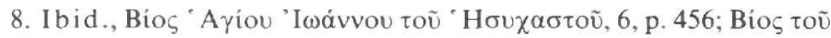

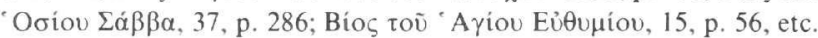




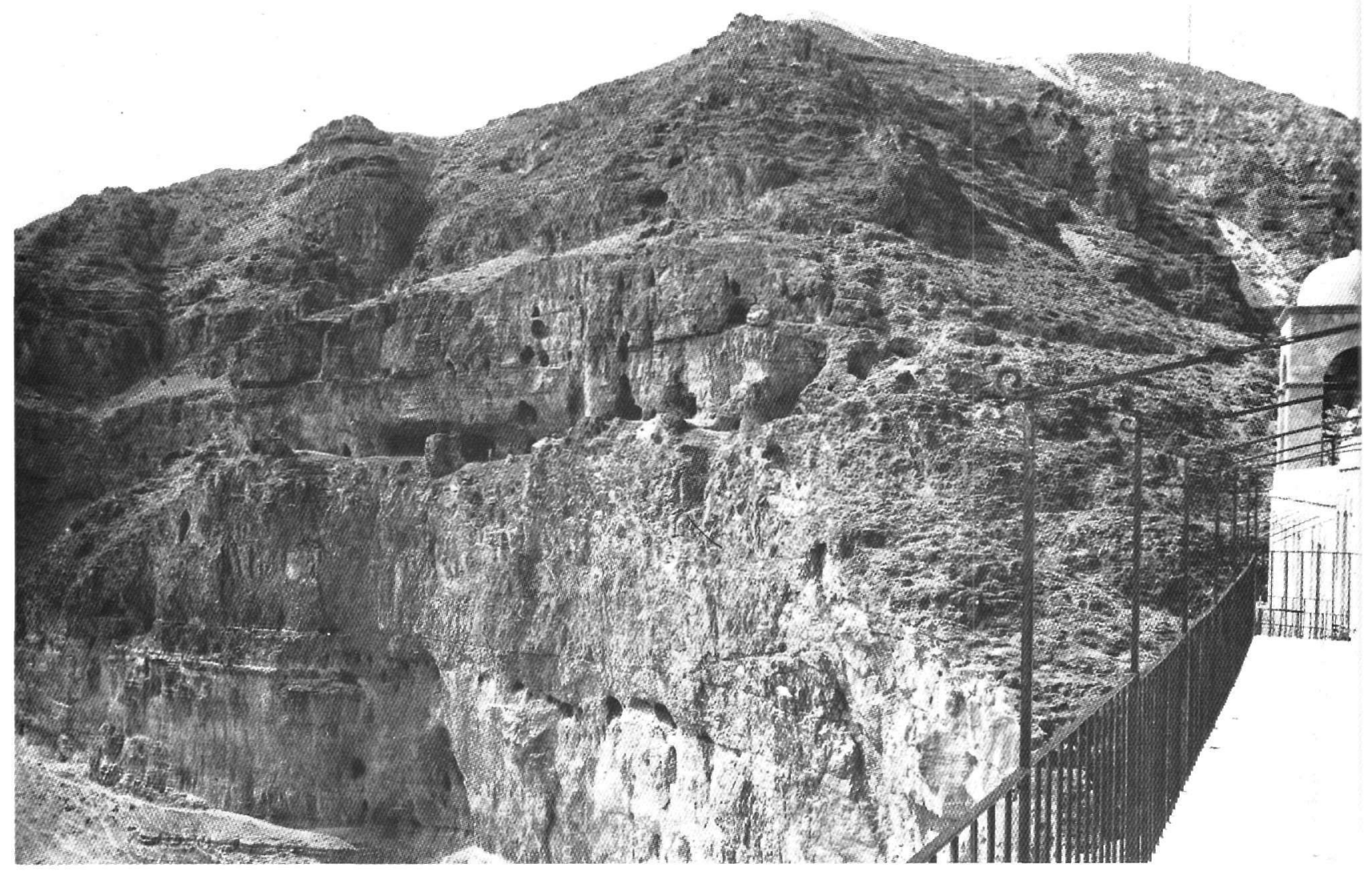

Fig. 8. Caves of Anachorites on the clifts overlooking the Valley of Jericho. The present Monastery of Quarantel (Sarantarion) is built on the ruins of an ancient Monastery.

on individual patterns. The archaeological evidence hitherto accumulated, provides a clear picture of both the internal structural organisation and the external appearance of the laura.

The ruins of the laura of St. Chariton (Figs 12 and 13), otherwise known as the "old laura", located in the gorge of Tekoa, south-east of Bethlehem, can be considered the best example for our study. The laura sits on top of the highest cliff overlooking the gorge and its ruins are spread over an area of more than 54.000 sq.m. It consists of three main elements: the coenobion of the laura, the stone-constructed individual cells spread over the top of the cliff and the natural caves along the upper terraces of the gorge, used either as cells for individuals or as living units for groups of monks. The coenobion of the laura, set up separately at the highest point of the monastery and surrounded by enclosure walls, had a triangular shape with three towers built on each one of its corners. Inside the walls of the coenobion were found the necessary buildings to serve the communal needs of the monastic community, such as the main church for
Sunday and feast prayers, the bakery and the refectory for occasional communal meals, the hostelry, stables and the cells for those monks, who were seconded to officiate in the community. The coenobion of the laura, with its enclosures walls and its massive towers could also give protection to all the anachorites of the monastery in times of danger or of predatory invasions, something which is often reported in the monastic chronicles. Tha individual cells built outside the walls of the coenobion, are also of extreme interest. They are dispersed all over the area leaving enough empty space inbetween for undisturbed solitary living. Almost all are open to a south or south-westerly direction for climatic reasons. Many possessed a small garden and a water reservoir while a few of them are divided into two inner rooms. They were comfortable and spacious with an average area of 20 sq.m. The largest had up to 50 sq.m. of space, while the smallest, 15 sq.m.

Narrow pathways, often cut into the rock, connected the individual cells with the coenobion. In contrast to the stone built cells located on the inclined top of the 


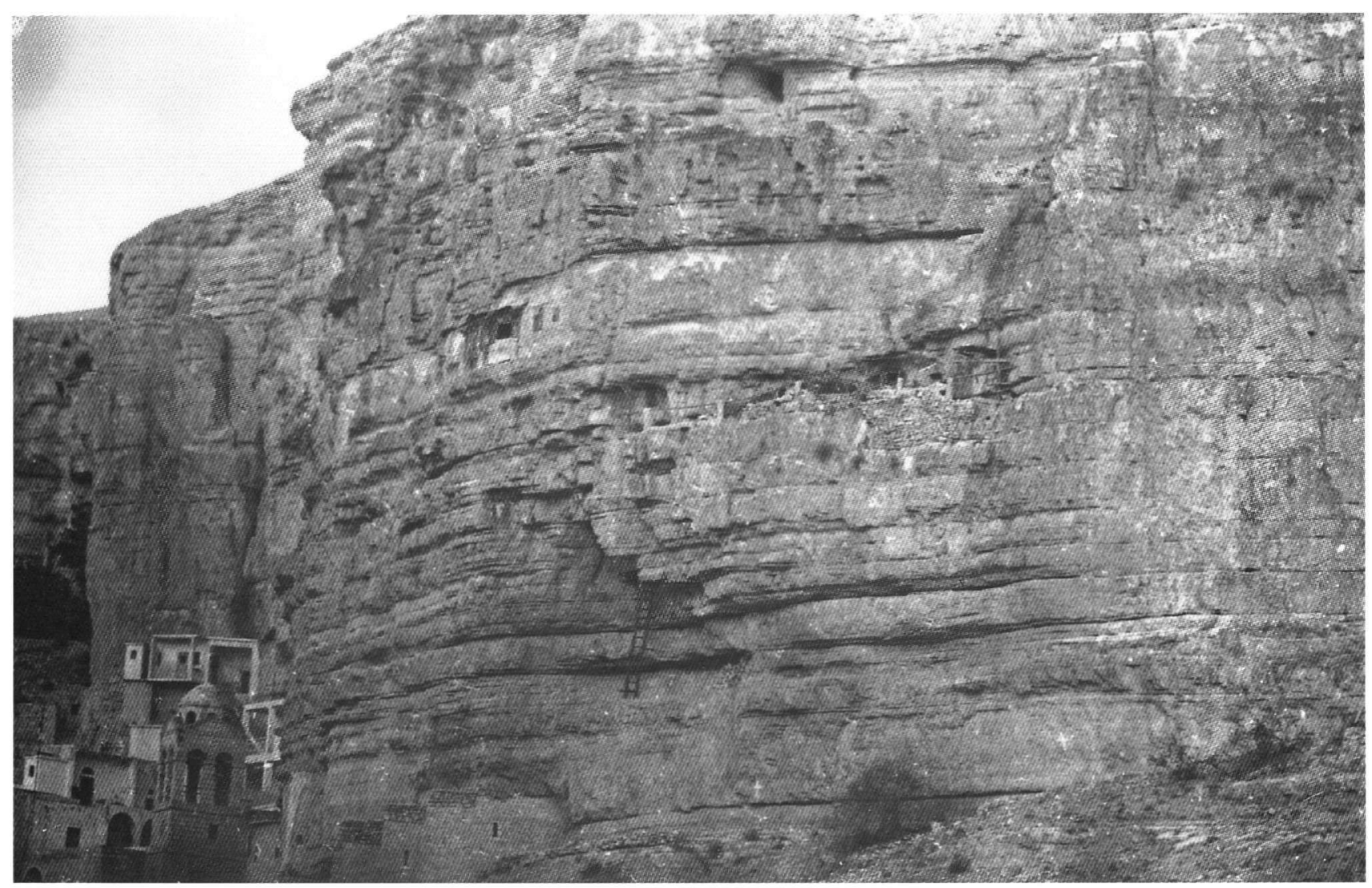

Fig. 9. The Monastery of St. John the Chozebite in Wadi el-Quilt in the Judean Desert. The caves inhabited by the Anachorites are noticable on the western clift.

cliff, the natural caves of the laura were used for a more austere solitary and were found along the upper terraces of the gorge at a small distance from the coenobion. Among them the most interesting is the cave of St. Chariton, known as the "hanging cave".

The water supply in the laura was also well planned. Appart from the many small cisterns spread over the whole area for the regular daily water supply of individual monks, the laura possessed a large water reservoir built on a high point from where the water could easily run by gravitation in any direction. The reservoir is distinguished by its fine construction as well in its great capacity; fully filled it could store more than 140 cubic meters of drinkable water ${ }^{9}$.

A similar arrangement, of the various structural elements was also found in other lauras in the Judean Desert. The "great laura" founded by St. Sabbas on the western cliff of the Kidron valley can be considered as a second example (Fig. 14). The monastery, in its present state, preserves a reduced form of the original huge laura, the area of which extended to more than 20.000 sq. meters. The coenobion of the laura occupied the area of the present monastery, while the cells were spread on both cliffs of the gorge to a distance of one thousand meters. The archaeological investigation, recently undertaken, yielded valuable evidence on its inner organisation, on the plan and construction of the individual cells and on the conditions of life of the monks. The numerous isolation cells nicely constructed and well equipped with small private cisterns, courtyards and small terraces for seasonal gardening, afforded the monks a sort of careless and comfortable solitude rather than a hard-to-bear stay (Fig. 15). The construction plan of the individual cells took care of all the possible details including the topographical and the climatic. As in, almost, all the monasteries of the Judean Desert, so too in the great laura, the cells opened purposely to a southerly direction, so as to enjoy as much as possible sun light and to protect the occupants from the severe

9. Hirschfeld, Monasteries, pp. 153-154. 


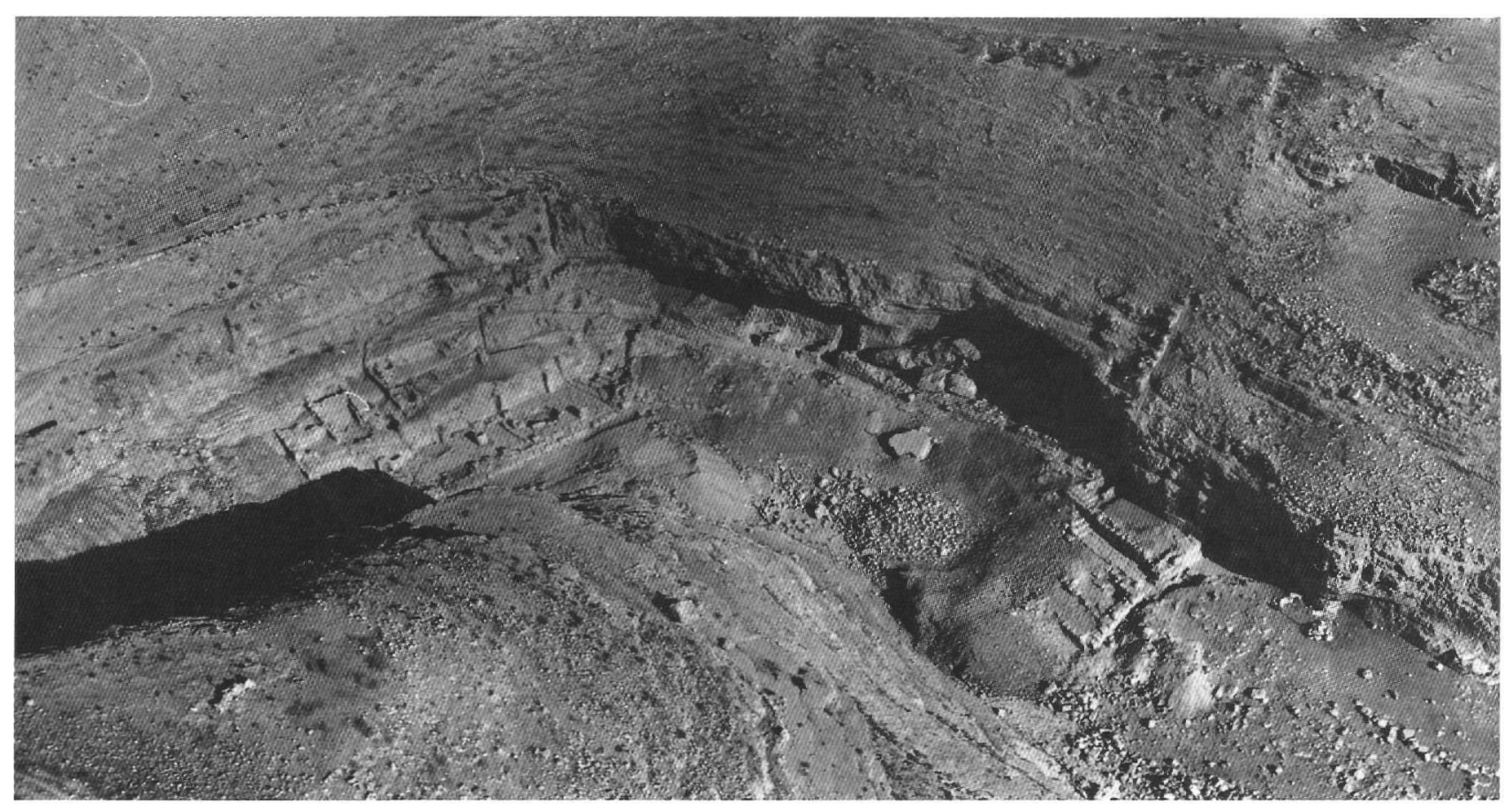

Fig. 10. Aerial view of the E-Deir Coenobion discovered in Wadi Arugot in the Judean Desert. (Courtesy of I. Hirschfeld).

and cold western winds that so often blow in the desert. In addition, the construction of the monastery complex on the steep and clumsy cliff of the gorge of Kidron, illustrates the technical and architectural ability of its founders. Certainly, this was an achievement of a genius architect, as also were the rest of the monasteries founded in the wilderness of Judea.

The establishment of most of the monasteries in the Holyland was, as already pointed out, the accomplishment of private initiative, energetic monks or accepted spiritual leaders of monachism, and they were those, who decided if and when to found a monastery and of what order. Often, however, the literary sources mention cases in which the secular imperial authorities or the institutional church took the initiative, both in the foundation and in the financial expenses involved. The best example of such a case was the erection of the fortress-like monastery in south Sinai, which in later times became known as the monastery of St. Catherine $^{10}$. Few similar cases of imperial involvement are mentioned in the cources in connection with monasteries founded in Jerusalem or in the Judean Desert. More precisely, we are told that the emperor Justinian erected in Jerusalem, at the expense of the imperial treasury the magnificent "church and monastery of Theotokos", otherwise known as the "Nea"ll.
In the biography of St. Theodosios we are told that the emperor Anastasios erected on the River Jordan at the spot where John the Baptist lived, a large monastery. The same source adds, that the emperor also provided, from the imperial treasury, an annual sum of six solidi for the subsistence of each of the monks who lived there. (Theodosius, 121.20) ${ }^{12}$. The present building of the monastery of St. Prodromos on the Jordan River, though built on the ruins of the original monastery founded by the emperor Anastasios, is a construction of a much later period, thus, it cannot give a clear picture of the original building. A few years ago, one of the burial-chambers of the early monastery was accidentally discovered. It contained the skeletal remains of several hundred monks. The discovery, though extremely interesting, can only hint to the great number of monks who lived there during the 5 th and 6 th centuries A.D.

The recent discovery of parts of the Theotokos church and monastery of Justinian in Jerusalem are, on the other hand, too fragmentary to help us sketch out the overall plan of this imperial complex of buildings. Nevertheless, their massiveness as well as their elaborate architectural decoration, pointed to how grandiose and magnificent the entire building was ${ }^{13}$.

A much better idea of the imperial monasteries built in the Holyland in the Early Byzantine period can be de- 
11

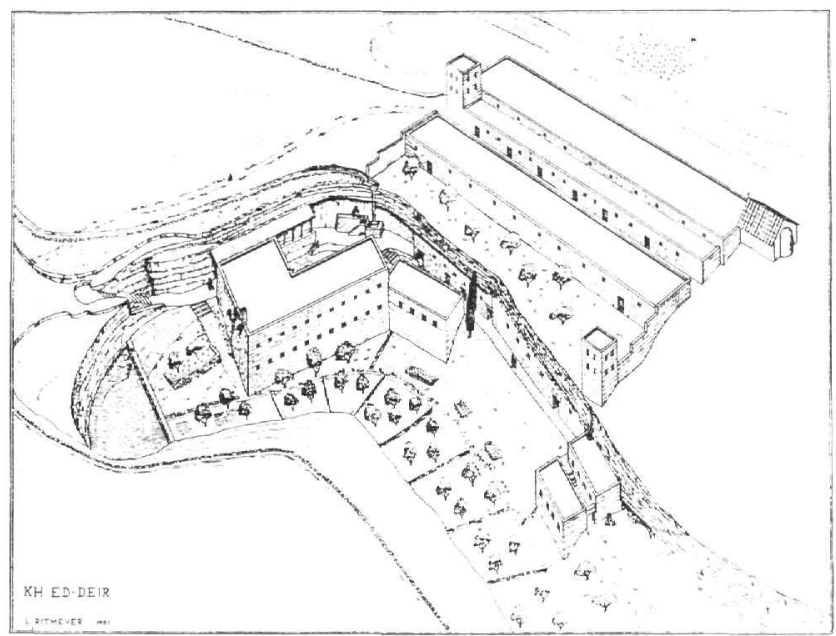

Fig. 11. The E-Deir Coenobion in Wadi Arugot. The reconstruction of the various buildings is based on the actual remains discovered during Archaeological Excavations. (Courtesy of I. Hirschfeld).

Fig. 12. Remains of the Laura of St. Chariton. (Courtesy of I. Hirschfeld).

12

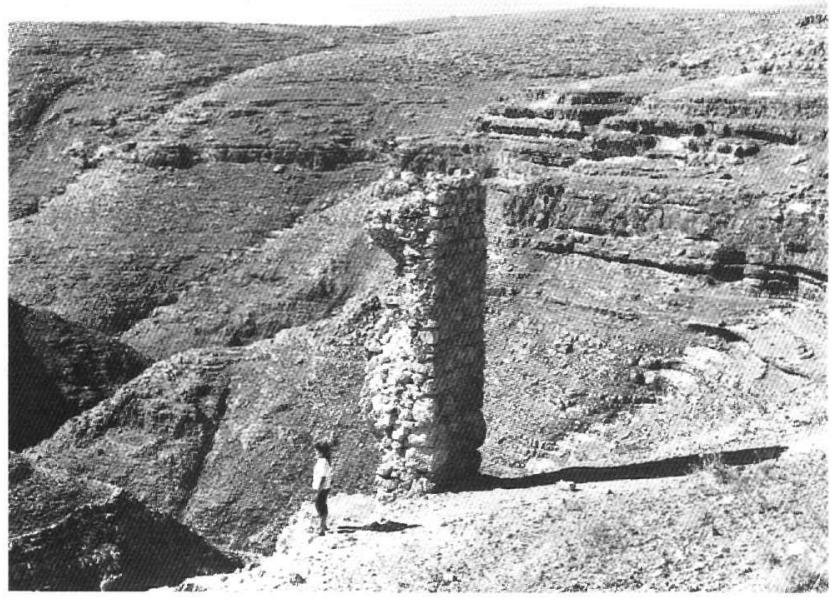

duced from St. Catherine's monastery in southern Sinai. Although, the later structural additions and interventions have, to a great extent, altered the original internal organisation of the structures, it still preserves much of the original planning and buildings. If we are to believe the written testimonies, and there is no reason why not, Justinian did not intend to create a monastic centre, but rather to grant a fortified shelter to an already existing and flourishing monastic community. Therefore, the vigour of the Justinianic building, which still impresses, is mainly manifested in its fortified outer walls. The arrangement of the various buildings within these walls, and the sort of the buildings constructed, apart from those dedicated to the most venerated holy spots included, did not differ much from other regular monasteries in the Holyland of the same period. The imperial intervention in the planning and the use of the imperial treasury for the construction are noticeable in the materials used and in the ability to employ excellent technicians and artists in this remote location. Obviously, the artistic decoration, within the monastery and especially within its venerated holy places, was on a much higher level than in monasteries of private initiative.

Recently, the archaeological spade was fortunate to uncover an entire monastery, the construction of which was undertaken in the framework of an institutional initiative, though not necessarily imperial. The monastery in question is that of Martyrios (Fig. 5), already mentioned above. The initial establishment of the monastery began in the middle of the 5th century by the monk Martyrios the Cappadocian. Martyrios, according to Cyril the Scythopolitan, came from Egypt and after spending some time with Euthymios the Great, secluded himself in a cave he found at a distance of about 15 stadia from his famous laura. Later on, Cyril says, at the site of the cave of Martyrios was founded a famous monastery named after him. The monastery was certainly founded in the years 478 to 486 when Martyrios was seated on the patriarchal throne of Jerusalem. Only then, as the head of the see of Jerusalem, did Martyrios have the ability and the financial facility to build such a huge and well equipped monastery as the archaeological excavations have revealed.

The general plan of the monastery and the distribution of the various functional departments, the splendour of the buildings, especially those of communal use and the high level of the craftsmanship of technical construction, as well as the artistic ability expressed in the laying and designing of the mosaic pavements, testify to the hand of an excellent architect-planner but mostly the disposal of great financial resources. These means could come only from a well established institution, in this case form the official church of Jerusalem, or from the state treasury or from both. Martyrios in the years of his patriarchate was in position to undertake and succeed in

10. Ibid., pp. 137-139.

11. Procopius, Buildings, V, vi. (The Loeb Classical Library, VII.)

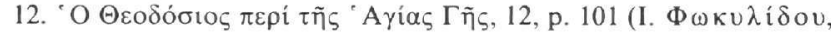

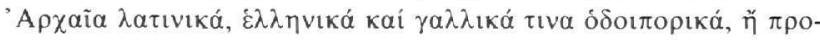

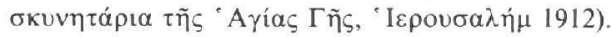

13. N. A vigad, Discovering Jerusalem, Jerusalem 1980, pp. 229-246. 


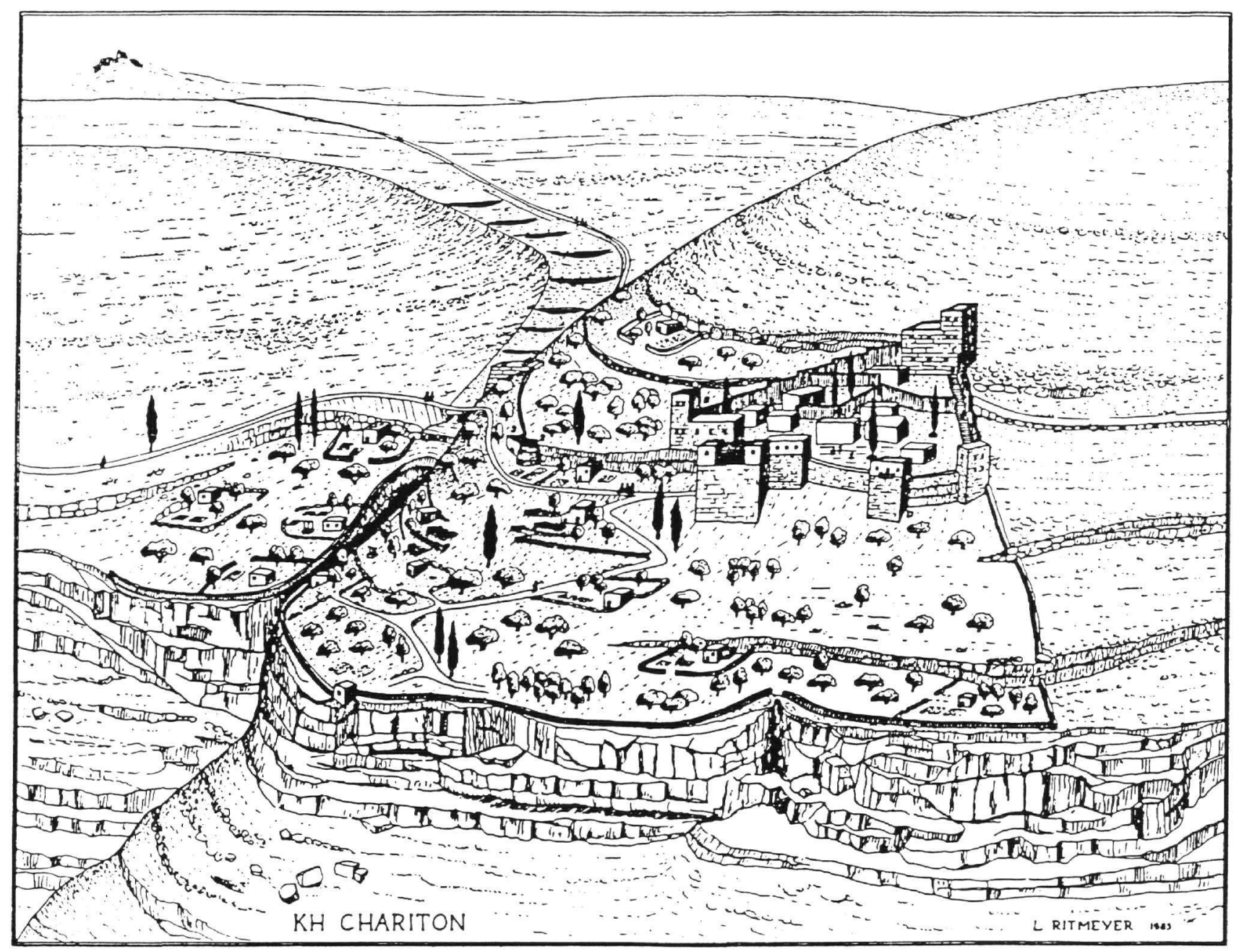

Fig. 13. The Laura of St. Chariton with its various structural components, built on the slope of Wadi Charitun near the site of ancient Tekoa. (Courtesy of I. Hirschfeld).

such an expensive project. The entire complex, occupying an area of approximately 10.000 sq.m., consisted of: two hostelries, the main entrance, the area of the main church, the northern wing with the cave of St. Martyrios and the refectory, the area of the great cistern with the gardens and the central spacious courtyard. Amidst the large buildings fulfilling different communal functions, were inserted various auxiliary spaces as well as small living quarters. The monks lived in the rooms on the upper floor, for the existence of which was found clear archaeological evidence. In such a huge monastery, which could populate several hundred monks and at the same time give services to many pilgrims and visitors, and adequate water supply ought to be a major concern to its planners. Indeed, the cisterns and water reservoirs found in the monastery, within and outside the walls, could collect the tremendous amount of, approximately, 20-30 thousand cubic meters of water. The construction of the cisterns, as well as the sophisticated trench system used to amass every drop of rain water and also to drain in the floodwater from outside, provoke admiration and astonishment. The water flow was under full control through drainage systems and devices allowing any possible diversion according to the requirements of the monastery.

A considerable portion of the water accumulated was used to irrigate the gardens of the monastery found inside and outside its walls. The presence of kitchen gardens in the monasteries of the Holyland was very common. The monks grew various kinds of vegetables and medicinal plants in them.

In the general layout of the monastery special attention 


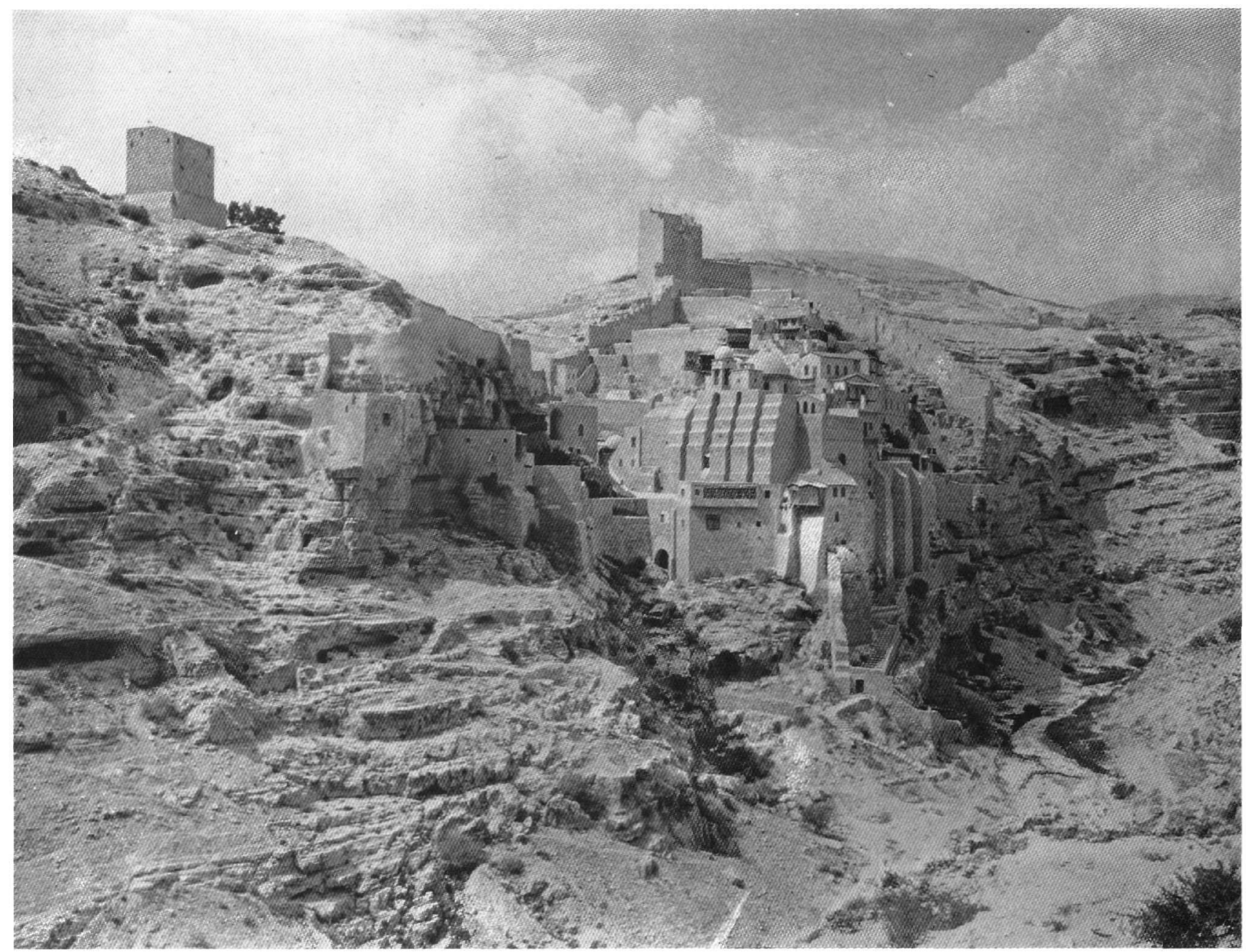

Fig. 14. The great Laura of St. Sabas. The present Monastery is located on that first founded in 478 A.D.

was given to the spaces dedicated to religious needs, and first of all to the church. The main church of the monastery was a complex of buildings occupying the entire central portion of the eastern wing. It consisted of the prayer-hall of the church, the apse, the narthex, the entrance hall, a chapel attached to the southern side of the church and of many other rooms and auxiliary spaces. All the spaces of the complex were paved with coloured mosaics representing a rich variety of decorative motives executed to high artistic standards. One of the rooms of the complex, was used as a burial place for the most distinguished persons of the monastery, the abbots. The tomb, dug in the centre of the room, was covered by a reddish stone slab decorated with a cross and two branches. Above them was written in Greek:

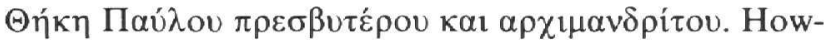

ever, when opened it contained the skeletons of ten persons. Obviously, it was a coenotafion used to bury the abbots of the monastery. To the south of the central church was found a beautiful chapel while a third one, larger and more impressive, was found on the south western corner of the monastery.

Of great significance was undoubtedly, the natural cave, which Martyrios chose for his monastic solitude, before the establishment of the monastery. Located to the north of the central court it constituted, from the beginning of the history of the monastery, a religious focal point, similar to all other monasteries in the Judean Desert. At a later phase it was turned into a burial place, probably, for the more distinguished monks. The spiritual and religious institutions of the monastery, clearly indicated the religious and monastic character of the 
community. Great attention was paid to the external appearance of the religious areas as well as to their internal decoration, all of which provided the necessary spaces, atmosphere and conditions for the practice of the religious duties of the monks.

Equally, great attention was paid to the mundane needs of the monks. The spaces and the facilities dedicated to them clearly reveal that the worldly concerns were not at all neglected. On the contrary, great efforts were put to lend them a monumental representation and as much as possible comfort. The spacious open courtyards, the gardens and the arched corridors provided the monks place for physical relaxation and social intercourse during their spare time. The upper storey, where the dormitories were found, was not preserved. We can only guess that they were built in such a way as to afford all possible comfort and acceptable privacy, certainly not abstemious living.

The refectory was a great surprise to the excavators of the monastery as it is one of the most impressive archaeological discoveries of the Holyland. It consisted of a complex of buildings, such as an entry hall, storage rooms, an underground cellar for the wines of the monastery, a spacious kitchen of two storeys and a huge and an impressive dining-room. The kitchen, so far a unique discovery in the Byzantine archaeological chronicles of the Holyland, consisted of a large room, $21 \times 6 \mathrm{~m}$. equipped with all the necessary cooking instruments and installations. It was attached to the dining-room but was on a higher elevation. On the wall separating the two units was opened a large lattice through which food was served, reminding us of modern kitchens. Above it was a second floor, used probably, as a small and more intimate dining-room. Both storeys were paved with coloured mosaics. The dining-room was the most magnificent building of the entire complex. The huge hall, $26.50 \times 12 \mathrm{~m}$., built on a basilica plan and paved with most beautiful and elegant coloured mosaics (Fig. 7) could easily accommodate several hundred diners. The monks, undoubtedly, sat and ate on portable wooden benches and tables. The solid constructed benches found along the long walls of the hall were, probably, used as sitting places at times when the hall was used for the regular communal meetings of the monastery. The entire refectory wing, with the kitchen and the other auxiliary spaces, as well as the abundance of the domestic utensils, such as cooking pots, bowls, cups, jugs etc., found in it, is a interesting archaeological discovery. It clarifies not only the eating habits of the monks in Byzantine Palestine but it also sheds valuable light on their menu. Certainly, the most complex and up-to-date kitchen of Martyrios monastery, as well as

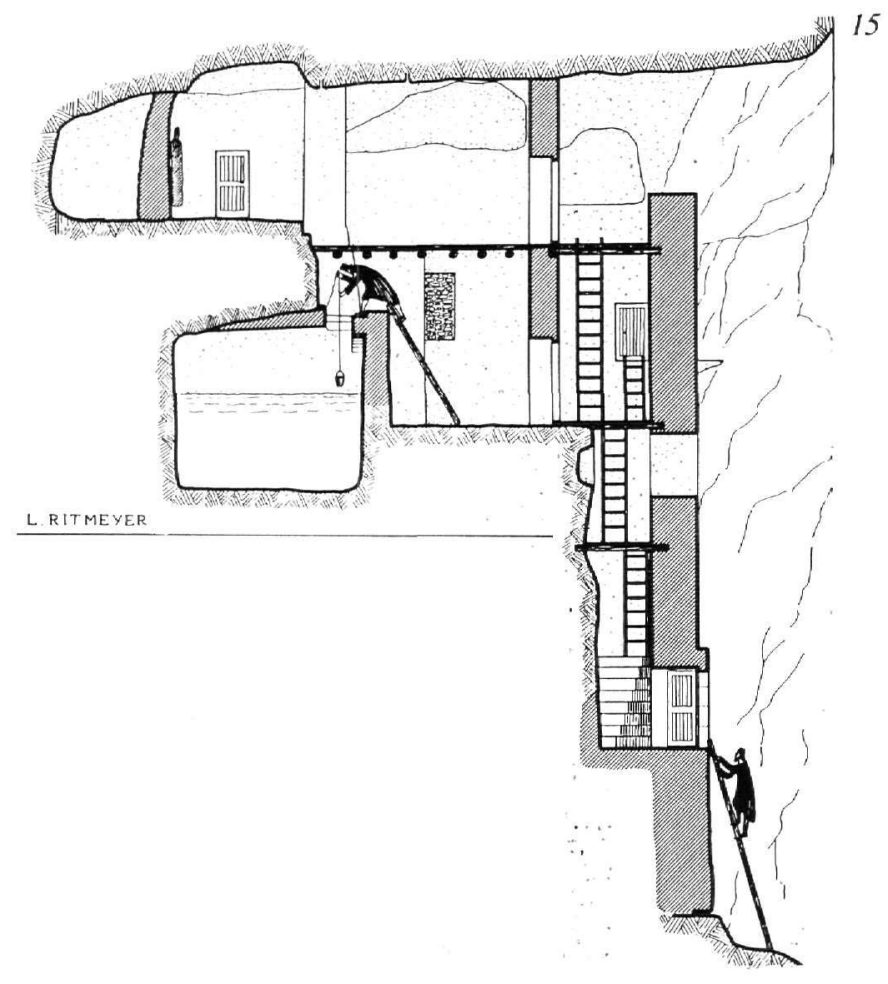

Fig. 15. The Hermitage of John Hesychastes in the Laura of St. Sabas in Wadi e-Nar. (Courtesy of Y. Patrich).

Fig. 16. The Hermitage of an unknown Anachorite in Ein-esSakhara in the Judean Desert. (Courtesy of I. Hirschfeld).

the well equipped kitchens of many other monasteries, coenobia or lauras, discovered in the Judean Desert, were not destined to cook the frugal meals of the monks as often described by the literary sources. We may also guess that the dry biscuit of the ascetic was not the only course served in these magnificent refectories. As a rule, in almost all the monasteries discovered, whether in the desert or amidst populated areas, there was preserved a balance between the spiritual-religious and the mundane demands of the monks.

In some monasteries, we may even assume, that the concerns of worldly demands surpassed those of the spirit. Thus, the monastery of Martyrios operated a regular bathhouse, built according to the rules and principles of the secular public bath-houses of the RomanByzantine period. It consisted of three main parts: the heated room -caldarium- with its typical hypocaust, the cold-room - frigidarium - and the dressing room -apodyterion. The heated-room contained a separated cabin with a private bath installation, very probably for the abbot of the monastery. The location of the bathhouse, within the walls, leaves no doubt, that the 


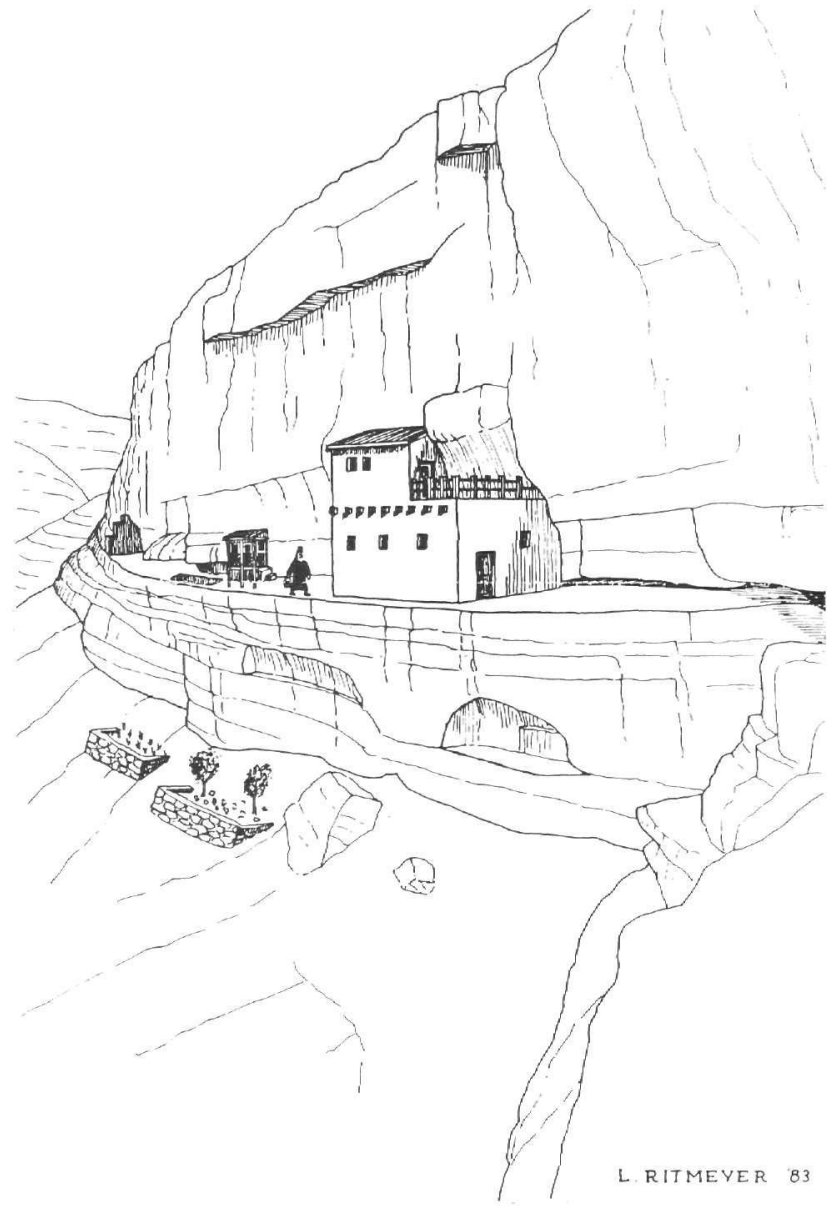

planners of the monastery from the beginning intended to put it at the monk's disposal.

The leisure and, so to say, the good-living, in well constructed and well organised monasteries was not a privilege shared equally by all the monks in the Holyland. Only, the coenobia and especially those of a wealthy patron, could provide the conditions for really comfortable living. On the other hand, in the lauras monastic life was tougher due to the particular way the community was organised, so affording private initiative in the spiritual exercise of the monk's life as well as in the way of conducting his private life.

The vast majority of the monks in the Holyland lived in the framework of monasteries of either kind, lauras or coenobia. However, many others chose anachoretic solitude and lived in absolute isolation in regions far away from human habitation. Remote spots in the interior regions of the desert, as a rule, were preferred for seclusion, but there were also many exceptions. The archaeological surveys have discovered a considerable number of isolated hermitages in the valley of Jericho (Fig. 8) and other places not necessarily in the desert ${ }^{14}$. Very often, many anachorites settled in the vicinity of lauras, or coenobia, mainly because they wanted to be close to a church. These independent hermitages consisted, mainly, of a natural cave refashioned to afford necessary and sufficient ascetic conditions and provide for the limited physical needs of the anachorites. The Judean wilderness (Fig. 9), the ravines of Negev and the granite mountains of southern Sinai, offered plenty of such natural shelters.

Certainly, a long term sojourn in the caves, as usually was the case with the hermits, was not very pleasant. Yet, as in the organised monasteries, so also in the isolated cave hermitages, the human hand of the ascetic intervened to mitigate against the cruelty of the desert and to produce more indulgent living conditions. Thus, the opening of the cave was usually blocked up leaving only a small opening. The inner space of the cave was divided into two separated cells, one of which was used as a chapel and the other for habitation. In almost all the hermitages some arrangements were made for water supply, while in a few of them a small garden was added in front of the opening of the cave for seasonal vegetables. Very often, the intervention of the hermit was even more drastic, altering altogether the shape of the cave by hewing in the rock, or by adding stone constructed buildings. Some of the cave-hermitages discovered in the Judean Desert are self-sufficient units, allowing a stay of long duration, given that the monk had made all the necessary food provisions. Such a cave-hermitage is one used by the famous ascetic, St. John the Hysichastes (Fig. 15). St. John, though a member of the great laura of St. Sabbas, was allowed to conduct a life of an independent anachorite. His hermitage was on the eastern cliff of the Kidron valley, not far from the laura. Originally, it was a large natural rock fissure, blocked by a stone wall, 11 meters high. In its lower part, the wall formed a sort of a vertical shaft through which the ascetic could climb up by ladder. Above it was a two storey space, the lower one consisting of a rectangular habitation cell and a large cistern collecting the floodwater from outside the cave. The upper storey contained a spacious and nicely constructed chapel.

In an unidentified laura, the ruins of which were recently surveyed and partly excavated in Wadi Danubia, to the north-west of Jerusalem, were discovered the most interesting hermitages. One of them was unique in its location and form. The hermitage was located in a large rock crevice hanged over the southern steep cliff of the

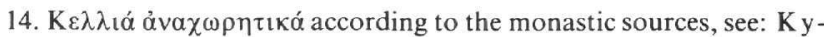

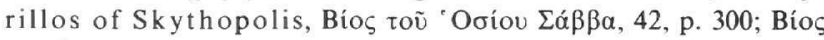

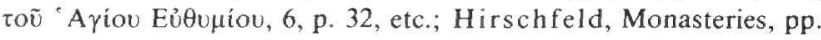
207-210. 
ravine and at a distance of about 700 meters to the west of the main church of the laura. To reach the hermitage one had to descend an abrupt rocky slope and step along a narrow and quite impassable path partly hewn in the rock. The ascetic who lived in such an isolated place was connected to the laura only formally. Certainly his visits to the laura were not daily, not even weekly. In other words he was an independent anachorite living within, or most probably on the edge of the monastery. The natural rock fissure was large and deep enough as form in front of it a spacious terrace used by the ascetic as a small garden. The inner space of the natural crack could easily be used as prayer-place, a sort of chapel (Fig. 16). High, on the smooth rock to the left side of the mouth of the cave, was hewn a rectangular opening. At first sight, it would seem quite impossible to climb but the moment one started the ascent was easy, thanks to the foresight of the monk. Exactly under the opening were cut into the rock two vertical rows of shallow depressions. The sockets were arranged in such a way so as to enable an almost unsighted climb. The opening led into a hewn cave, large enough for one person. Just below the entrance of the cave was cut into the rock a narrow level projection leading to a deep, well cut "couch". The couch offered a comfortable seat over looking the wonderful view of the ravine below. Under the couch was out two small depressions where the feet were placed, thus the entire arrangement provided a most pleasant easy-chair.

The most astonishing supplement in this hermitage was found below in the garden terrace. Just in front of the mouth of the crack a heavy block of rock raised up like a column supporting the roof of the cave. From its top a slender stalactite was suspended, from the end of which, every twenty seconds, a thick drop of water fell. The water was collected in a small basin dug in the middle of the rock-pillar. Next to the basin was cut an horizontal shelf-like projection, large enough to hold a small cup. The shelf had a concave surface and a slight groove leading to the small basin. Everything was done carefully and with such precision so as not to waste even a single drop of the precious liquid. The tiny spring threw down its drops, with the same frequency throughout the year, it still does. In the duration of a day and a night the ascetic could collect about one litre of water. We can certainly assume, that this was his daily consumption, because no other arrangements for the storing of water were found in the hermitage. The hermitage just described, with all its supplements, clearly testifies to the human aspect of early Christian asceticism in the Holyland.

So far, no archaeological discovery has witnessed any monastic extremity or self-castigation. The monks of the Holyland, even the most austere ascetics, never broke off their connections with the outside world from which originally they came and never forgot their own human nature. Within their monasteries, their hermitages or within the new society they built, the body and soul were equally treated, creating thus, a balanced society, which did not lack even the small pleasures of life. The ascetic, whose hermitage was just described, spared neither time nor labour, in order to create for himself a suitable residence where body and soul could live in harmony and without painful privations. Seated on that comfortable couch, he carved on the rocky cliff of his cave and looking down on the breathtaking view of the deep ravine or ahead to the endless Judean Desert while hearing the pleasant sound of the drops of cool, fresh water, he certainly was experiencing hours of bodily relaxation and joy. Perhaps, who knows, it was through this physical delight, that he found the way of union with his Creator. Some other ascetics put great efforts into creating, not only convenient, but also pleasant looking and artistically decorated hermitages. Thus, a hermitage, discovered in the valley between Jericho and the river Jordan, was entirely paved with coloured mosaics, while many others discovered in the desert had iconographed chapels ${ }^{15}$.

In general, all the hermitages discovered in the Holyland reflect a real concern in creating the most basic conditions for a decent physical human life.

Most of the archaeological evidence brought above dealt with coenobia, lauras and hermitages built either in the deserts or on places having connection with some particular biblical event. However, other regions also attracted monastic settlement. The archaeological investigations have brought to light remains of many monasteries built in every possible place without taking into consideration any special topographical, climatic or demographic criterion. Populated areas, villages and towns were subjected to monastic settlement, if not with equal enthusiasm as the Judean Desert, southern Sinai and Holy Places but at least without any prejudice. The three monastic patterns, the coenobiac, laureotic and anachoretic or ascetic were the only ideological conceptions in practice everywhere. Yet, life in general differed from place to place and from monastery to monastery. The way of life of a monk, as well as his daily occupation differed even from coenobion to coenobion or from laura to laura. The coenobites living in a monastery built in the desert or in arid areas had a different standard of living than their associates living in fertile regions or amidst populated towns and villages. Archaeology can not clearly clarify or define the way of living or the 
standard of living in the monasteries discovered, except for external conditions, architectural, artistic and material, which effected the life of the individual monk or the entire community. Very often, we have conclusive evidence as to the source, or at least one of the sources of livelihood of a given monastery. Its topographical location, the installations incorporated, the small finds and sometimes the distinctive mosaic decoration used in its pavements reveal the kind of occupation monks practiced to make their own living. Thus, in the last three decades of intensive archaeological work were discovered a great number of monasteries providing clear evidence, that they were involved in agriculture, not only as a source of self-maintenance but also on a profit making basis.

Generally speaking, all the monasteries, lauras or coenobia and even the most remote hermitages, were involved in some sort of agriculture. As we have seen, every monastery and every hermitage had its own garden for the provision of the necessary kitchen vegetables. Very often the monasteries maintained different sorts of agricultural installations used for self-production of commodities such as oil, wine and meal. Thus, olive and wine presses or grinding stones are found in almost all of them.

It is understood, that monasteries located in the heart of desert or in entirely arid areas could only afford a tiny cultivatable terrain for the most indispensable vegetables, while those located in fertile regions could maintain large gardens and sometimes tillable fields too. However, the existence of domestic agricultural installations and monastery gardens, under the supervision of

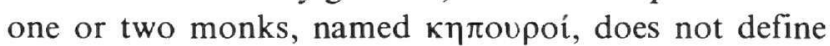
the main occupation practiced by the monastery as an organised community but rather the provident mind of the founder of the monastery or of its abbot.

On the other hand, the farm-monasteries discovered in various regions point to the fact, that agriculture was the one and only occupation of the monks who lived in them, apart from their religions duties.

As a rule, such monasteries were located not in desert or arid areas but in regions where normal agriculture was possible. Grape and olive growing were the sorts of agriculture monks were mostly engaged in, though, we may surmise that crops and vegetables were not excluded. The farm-monasteries were usually small in size and all of them were built on a similar plan; a rectangular two storey building consisting of a central open courtyard surrounded by rooms of different size and function. In the lower storey were found the chapel, store-rooms, the kitchen, refectory and the various agricultural installations, such as grinding-stones, oil and wine-presses, etc. On the upper were the cells of the monks.

Sometimes, the practice of agriculture is reflected in the type and quantity of tools discovered or even in the motifs chosen to decorate mosaic pavements within the monasteries. Thus, in Skythopolis, the ancient city of Beth-Shean, was discovered a 6th century monastery, the main hall of which was paved with coloured mosaics depicting a circular representation of the labours of the twelve months grouped around the sun and moon and all personified. Another room, in the same monastery, had a mosaic pavement illustrating various agricultural activities and almost all the phases of viticulture. These mosaic illustrations as well as a large group of toiling tools discovered, leave no doubt at all, that agriculture was the favoured occupation of the monks of this monastery ${ }^{16}$.

In another monastery discovered at Shelomi, a few kilometres north of Acco-Ptolemais, were found great quantities of various crops, such as wheat and barley, olive kernels and grape pips, all of which were the basic products of the Roman and Byzantine farm-villas. Using the technique of flotation, the excavator also discovered large quantities of fodder plants used for cattle, or most probably, for the raising of cows. However, the most interesting and unique discovery in this monastery, which clearly indicated its involvement in agriculture, was a bronze bar of five Roman cubits length, used as an instrument for land measuring ${ }^{17}$. Near Beit-Hashita, in the Esdraelon valley, was discovered a small monastery the main produce of which was wine. Its ruins consist of a large open courtyard, on both sides of which were found the architectural remains representing the two main occupations of the monks who lived there, a well constructed chapel paved with coloured mosaics for prayer and an equally well constructed hall containing a winepress ${ }^{18}$.

These are only a few examples of the many other farmmonasteries discovered throughout the Holyland.

Th number of monks who lived in such monastic farms was very small, the largest of them could hardly accommodate ten monks. The agricultural installations, on the other hand, point to production on a larger scale than needed for home-consumption by their small community. Consequently, the question arises is whether they were branch monasteries associated with larger

15. D. C. Baramki, Excavations at New Testament Jericho and Khirbet en-Nitle.

16. Fitzgerald, Monastery at Beth-Shan, plates.

17. C. Dauphin, A Farm-Monastery at Shelomi.

18. Y. A hatoni, A Byzantine Farm-Monastery near Beth Hashitta, in Yediot 18 (1954), pp. 209-215 (in Hebrew). 


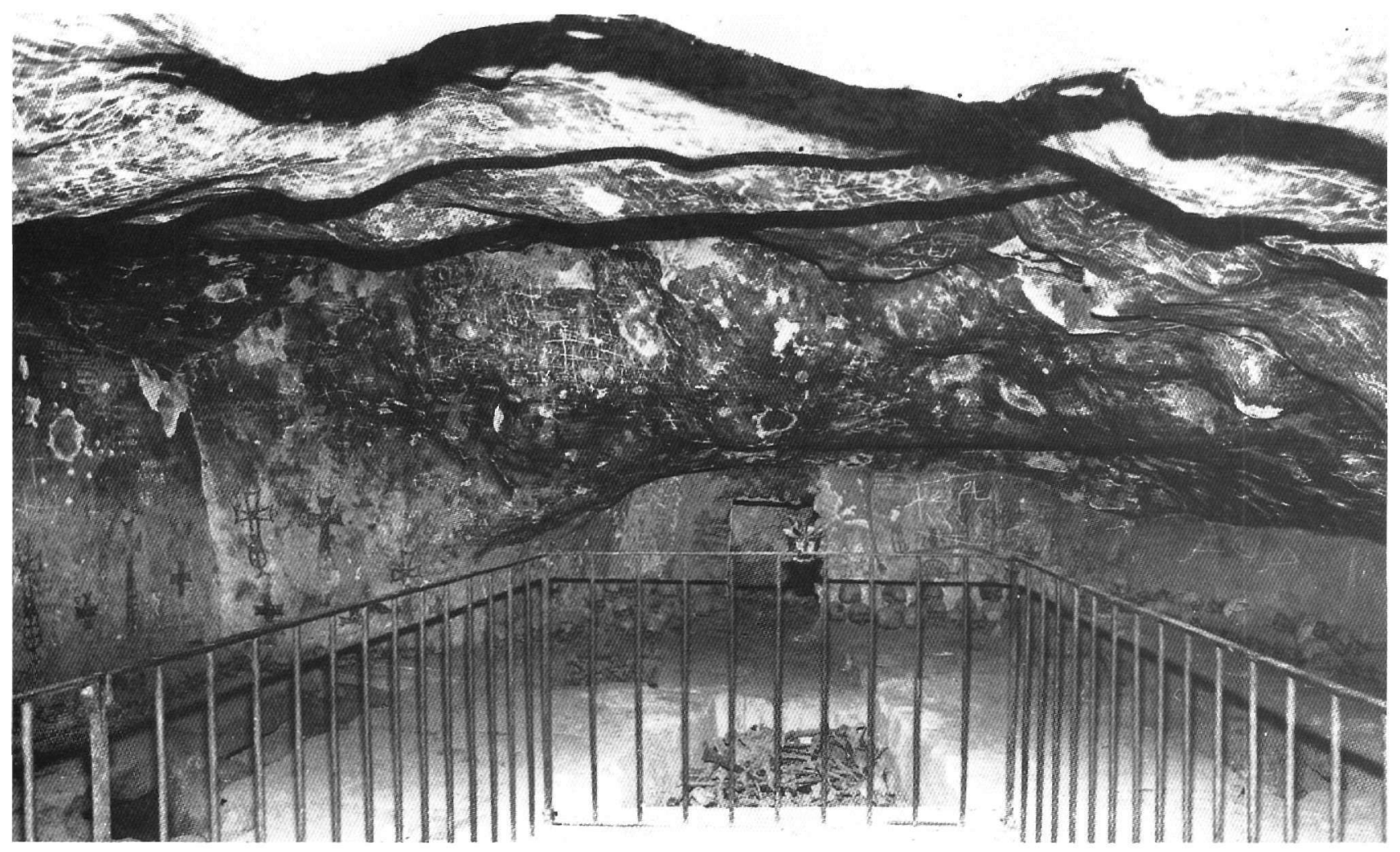

Fig. 17. The burial cave (coenotafion) of the ancient Monastery of St. John the Chozebite. Notice the drawings and paintings on the cave walls.

mother-monastic communities or were they independent monasteries organised on pure business grounds. The first assumption seems more plausible, though, of course we may not exclude the possibility that at least some of them were engaged in agriculture, not only as the main source for their living, but also on a profit basis. Manual work or physical toil of any sort, often compulsory, was one of the most significant innovations characterising the early monachism of the Holyland. Physical labour was imposed on the monks both, for securing their maintenance and for making profit for the benefit of the monastic community. Reserves, in cash, in agricultural or in handicrafts were necessary for the monastery in order to be able to provide its various charitable and social services (hospitals, orphanages, hostelries, etc.). As aforesaid, the different agricultural installations found within the monasteries or in their close vicinity, are supported by convincing archaeological evidence indicating the nature of labour monks were involved in.

Finally, another form of the multi-faceted monachism of the Holyland in the Byzantine period was that developed within the towns and villages alongside the secular urban or rural societies. Prima facie, such a cohabi- tation was against the very principles of monachism, one of the ideals of which was to avoid the secular world and to establish a different society far away from mundane temptations. However, the circumstances under which monastic life emerged and developed in the Holyland, permitted far reaching compromises both, in ideology and in the external way of life or behaviour. The presence of the monk amidst the urban centres, as the guardian of the holy places or as the host of the pilgrims, became indispensable and almost imperative. In addition, it was in the cities and villages where he could practice in full his philanthropic duties. The homes of the aged, the orphanages and the various other institutions, as well as the pilgrim hostelries were in Byzantine Palestine under the care of the church, while the monks were those who manned them and granted the service. Besides, the town monasteries were the reception centres and the nurseries, which maintained the mass reserves of novices for desert monachism. Almost all the monks who later became great founders of lauras and coenobia, such as St. Euthymios, St. Sabbas and St. Theodosios, were first absorbed in town monastic centres before turning to the desert.

Jerusalem, Bethlehem and Jericho, as the most impor- 
tant places of Christian pilgrimages, became in the Byzantine period centres of monastic habitation. In Jerusalem alone, according to the literary sources, several tens of monasteries were founded at different locations, preferably, at those connected with biblical events. Thus, on the Mount of Olives were recorded around fifteen monasteries or places of monastic settlement while Mount Zion, the Kidron valley, as well as the walled part of the city, were attractive to monks with equal enthusiasm. Many of them were so called "metochia", monastery dependencies, belonging to the great monasteries of the desert, while others formed various religious institutions maintained by monks. The majority, however, were independent convents established for the sake of the monastic idea. The same was true of Bethlehem where several monasteries were found in close vicinity to the Church of the Nativity and many others at the outskirts of the city. Most of the monasteries of Jericho, on the other hand, were monastic institutions providing their services, equally, to the poor and to the pilgrims.

Other great urban centres too, such as Caesarea, Skythopolis, Eleutheropolis, Nazareth etc. had their own monasteries interconnected with the general town plan. As a rule, they were attached to the parish churches, while their abbots ministered both, as hegumens and as spiritual leaders of the secular community. At Nessana, in the south-western part of Negev, was excavated a large monastery occupying the entire northern quarter of the city. Its rooms and various departments wrapped around the church thus producing an enormous complex of buildings, of $55 \times 45 \mathrm{~m}$. According to the evidence provided by the papyri discovered at the site, we learn that the abbots of this monastery were also the heads of the community of the town ${ }^{19}$. In another city in the Negev, Eboda, the monastery was constructed around the atrium of the church. It consisted of fifteen spacious rooms and halls providing enough place for habitation and for the various needs of the monks who lived there ${ }^{20}$. In Shivtah, again in the Negev, the buildings of the monastery were attached to the church in such a way as to create an almost independent insula. At the centre of the insula was found an open courtyard surrounded on all its sides by the rooms of the monastery, some twenty in number. Among them were storage rooms, winepresses and various other domestic installations ${ }^{21}$. In Nazareth too was excavated a small monastery attached to the southern side of the church of the Annunciation. It consisted of a double row of rooms and halls, all of them paved with coloured mosaics ${ }^{22}$. On the other hand, in Skythopolis was excavated a large monastery which stood far away the centre of the town and with no connection with any of the parish churches, yet, within the walls of the city. It had its own church, built on the north-eastern corner of the monastery ${ }^{23}$.

However, the most interesting monastic settlement located within an urban area was that discovered in Jerusalem, in the area south of the triple eastern Hulda Gate of the Temple Mount. The building was a three storied structure surrounded by walls, with only one gate on the west side. It had a pleasantly elaborated inner courtyard, two cisterns and a basement with rockcut tombs. The excavators deduced that the entire complex served, at some phase of its existence, as a monastic cloister and identified it as the one mentioned and described by the historian Theodosius in 530 A.D. as the monastery of the "enclosed nuns" 24 . According to the description of Theodosius, the monastery was built to accommodate six hundred nuns as permanent residents. Once admitted to the premises they never left and when they died they were buried there. The gate was opened only on rare occasions; goods were delivered over the walls and the water was drawn from their own cisterns ${ }^{25}$. If the identification is true, then we have an interesting case of a strictly ascetic and most abstemious monastic settlement located at the very heart of a most crowded and most temptatious place.

The number of town monasteries discovered by archaeology is limited, due to the fact, that most of the urban areas they were built in are still inhabited. Even in places, where excavations or any other sort of archaeological investigation is possible, the information is incomplete with concern to plans and material finds. Nevertheless, from the evidence accumulated, even in a fragmentary state, one may draw certain conclusions about the external appearance of these sorts of monasteries and on the conditions in which the monks lived. Certainly, the limited space allotted within the built-up areas on one hand and the particular social functions these monasteries were called upon to fulfil on the other, dictated much of their plan and constructural organisation. Thus, the various auxiliary spaces and household installations, such as store rooms, workshops, open courtyards, millstones, wine- or oilpresses etc., which

19. Excavations at Nessana, 1, London 1962, pp. 33-45, pls. LXIII, LXIV.

20. A. Negev, The Churches of the Central Negev, An Archaeological Survey, in Revue Biblique 81 (1974), pp. 400-422. See also A. Ovadia, Churches, pp. 23-26.

21. A. Ovadia, Churches, pp. 166-173.

22. B. Bagatt i, Excavations in Nazareth, Jerusalem 1969, pp. 77-114.

23. Fitzgerald, Monastery at Beth-Shan.

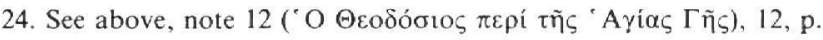
101.

25. B. Mazar, The Mountain of the Lord, New York 1975, p. 254. 
in the country and desert monasteries were almost constant elements, are not found in most of them. In many, even the church was not indispensable; the nearby secular church often providing the place for regular prayer of the monks.

So far, we have dealt with the remains, structures and various material objects, destined to serve the needs of living monks, but the archaeological discoveries have much to say, also, about the dead. Early Christian monachism did not make any clear or sharp distinction between the living and dead monks. Those monks who passed away continued to be related to the monastery and to form an unbroken part of the community. Consequently, they were not, physically, separated from the other, "live" part, nor were they neglected. They were buried within the walls of the monastery in places specially dedicated for them.

Thus, in the laura of St. Euthymios the burial place, the coenotaphion, was located at the very centre of the monastery. It consisted of a two-storey building, the lower of which was in underground. The individual tombs were all dug under the floor and covered by stone slabs. Next to the burial room was found another rectangular space filled with dismantled human skeletons. Apparently, the bones were collected there after they had been removed from the individual tombs in order to make room for new burials.

The same arrangement of burials and bone collection was found in other lauras and in well organised monasteries. Similarly, the burial place in the laura of St. Sabbas, still in use, is found in the most prominent spot of the monastery, under the court in front of the main church. In the monastery of St. George the Chozebite, burial was carried out in a large natural cave, found again not far from the main church and certainly, within the nucleus of the monastery, where the other communal buildings were located (Fig. 17). Today, this burial cave is seen outside the walls of the monastery but it was not so in Byzantine times, when the monastery was much larger than the modern one. The cave contained about fifteen individual cist type graves, arranged in two rows and a special cavity for the collection of the bones. The walls and the roof of the cave were covered with white plaster on which the names of the dead were written in black or red accompanied by crosses or other Christian symbols ${ }^{26}$.

In the Kastellion monastery, founded by St. Sabbas, the coenotafion consisted, again, of a rectangular natural cave. It contained eight trough-like tombs built of stone and covered by slabs. The walls of the cave was illustrated with figures representing various local monastic personalities. Natural caves or built-up spaces contain- ing multiple burials and ossuary spaces were used for the ordinary monks. Monks of a higher rank in the monastic hierarchy or monastery founders were treated in a different way. For them were allotted special graves located at the most prominent places within the monastery, preferably, very close to the church or sometimes even under it. In the monastery of Martyrios the grave of Paulos, the first abbot after Martyrios, as said above, was set in a rectangular room paved with coloured mosaics, just in front of the main church. Certainly, it was a coenotaphion for the abbots of the monastery, who headed the monastic community for a long period of time, probably up to the period when the monastery was destroyed and entirely abandoned in the course of the 8th century. Monks of second rank in the hierarchy of the community of the same monastery were buried in a natural cave found in the northern wing. The cave was apparently the place which Martyrios chose for his seclusion before the foundation of the monastery.

In Kursi, on the eastern bank of the Sea of Galilee, the abbots of the monastery and other distinguished monks were buried in an underground coenotaphion built under the diaconikon-chapel. It was a rectangular room with a vaulted roof, containing six large tombs. There were, in all, forty-four human skeletons including a woman's and that of a child. In St. Euthymios monastery, the grave of its founder was built conspicuously at the centre of the coenotaphion amidst the tombs of the ordinary monks. Finally, in the E-Deir monastery, the founder and most probably the abbots too, were buried in a small cave located at the very centre of the monastery. The burial cave was fronted by a small chapel paved with mosaics. Just before the opening of the cave was laid on the floor a Greek inscription of nine lines quoting two paragraphs, 52 and 53 of chapter 15 of the first epistle of Paul to Corinthians.

\section{EPILOGUE}

The present treatise only touched upon early Christian monachism of the Holyland in its material aspect, as it is reflected through the structural ruins and the material remains left behind and discovered by archaeology. No attempt was made to tell the full story, even in brief, of those people, men and women, who renounced the world and society, withdrew into the deserts and secluded themselves in caves or in walled monasteries to seek salvation. The only aim was to represent, in a comprehensive way, the archaeological discoveries made in recent years on this important subject and, if possible, to describe the physical and material framework within which the monastic community lived and developed. 
Looking at the archaeological evidence, one cannot but notice, that those early Christian monks, who disavowed the world and society, built in fact another social framework which was not much different from that they had deliberately avoided. It is also amazing to discover, how precisely, or sometimes even with what enthusiasm, the technical achievements of the secular society were copied in the very heart of the desert and were put to the service of the new society monks had built up for themselves.

Archaeology, dealing with visible and material evidence, cannot alone, reveal the full story of monachism, but neither can the literary sources and monk's biographies, which deal almost exclusively with beliefs, abstract ideas and human behaviour. Therefore, the utilisation of the archaeological discoveries becomes imperative in any objective literary and systematic composition analysing the various components of early Christian monachism, in general and in that of the Holyland in particular. The presentation of the indispensability of archaeology in any treatise on monachism was the second aim of the present article. Yet, beyond the fact that archaeology is capable of clarifying the material aspect of early monachism, it can also help analyse, through the evidence accumulated, the historical outline of this interesting religious movement, which so much effected the religious affairs of the church of Palestine. But this is beyond the objectives of our essay. However, we cannot complete our story on the Holyland monachism without relating both to its flourishing and to its grievous decline, as again, they are reflected through archaeological discoveries.

Thanks to archaeology, we can conclude that massive monachism in the Holyland began not before the mid5 th century and that it was only then that the first organised monasteries appeared. Its geographical expansion over the country together with the penetration of great masses of monks into the various regions of the Judean wilderness occurred only in the next, the 6th, century and in the beginning of the 7th. These years were, in fact, the golden age of the Holyland monachism. In no other period, before or after, was the desert inhabited in so great a density and never before or after were these barren regions made so worthy for human habitation using the most complex structural and technical innovations. The map of the monastic habitation in the desert looked like an endless city inhabited by many thousands of people. In face of such an amazing phenomenon, one is presented with a pragmatic and literal explanation to the well-known expression " $\pi \mathrm{o} \lambda_{\mathrm{I}}$

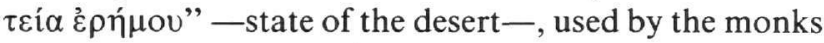
and here attached meaning additional to its sociological context. When the monks used this term in order to express the rules of their behaviour in their own society, they certainly were aware that such a "politeia" did in fact exist in reality.

The development and the prosperity of monachism in Byzantine Palestine were made possible thanks to the favourable political and religious situation prevailing in the country. The moment these prerequisites ceased to exist, monachism could not but decline. The first serious blow was inflicted by the Persian invasion in Palestine in A.D. 614 , and by the subsequent Persian occupation, which lasted to A.D. 629.

The marks left by Persian rage are visible on almost all the monasteries discovered. Many of them were totally destroyed, abandoned and never resettled again, while others were revived and managed to get reorganised when the menace of the invader was dispelled. There is no doubt that during the years of the Persian occupation, monastic life in the Holyland underwent a major modification, both in structural organisation and in way of behaviour. Moreover, the number of the monks decreased considerably, many were killed, many others moved to safer places and others decided to quit and return to the world from which they came. Consequently, living space within most of the monasteries was reduced and only the necessary spaces were kept in use. In the monastery at Kursi-Gergessa, the few monks who remained, even after the Persians were driven out of the country, reorganised their monastery in such a way as to respond to the new situation created. Thus, the guesthouse found at the main entrance was reshaped into a solid two-storey tower for defence or protection from possible future hostile raids. In addition, the porticos around the atrium of the church were blooked and used as storage spaces. Other structural modifications undertaken within the church complex indicate improvised repairs and alleviating activities. Generally speaking, the archaeological evidence confirms the severity of the Persian blow, as is reflected in the literary sources. In the Jordan valley, at the place when once stood the famous monastery of St. John the Baptist, was recently discovered a burial cave, dated to the 7th century A.D. containging hundreds of human skeletons rolled in linen sheets and thrown one on the top of the other. It was not a place for secondary burials nor a regular coenotaphion of prolonged use but a collective tomb where hundreds of dead were buried at one and the same time. On many of the skeletal remains were seen marks of violent death caused by arrow-heads or sharp weapons. These two instances described above give a clear picture

26. V. Meinaris, The Hermitage of St. John the Chozebite. 
of the disastrous blow to the monachism of the Holyland dealt by the Persians, yet, these are not the only dramatic events archaeology presents. Undoubtedly, the scourge of the Persian invasion would have healed if a second fatal blow was not followed shortly afterwards, namely, the Arab occupation and the subsequent abolition of the Byzantine temporal and spiritual sovereign power over Palestine. The Persian invasion checked for a while the development of monachism, but the Arab occupation wiped out its economic potential and the environmental conditions, which were so vital for the very existence of the monks. During the years of the wars of conquest and until the collapse of the Ummayad Dynasty, in the mid-8th century, monachism carried on undisturbed, sometimes even, buttressed by

\section{SELECTED BIBLIOGRAPHY}

P. A. Augustinović, Gerico e Dintorni, Jerusalemme 1951.

B. Bagatti, Origine del Monachismo in Palestine, in La Terra Santa 36 (1960), pp. 206-215.

I. Blake, El-Kuseir: A Hermitage in the Wilderness of Judaea, in PEQ 101 (1969), pp. 87-93.

P. Bar Adon, The Survey in the Judean Desert and in the Jordan Valley, in Judaea, Samaria and Golan, Archaeological Survey in the Year 1969, edited by M. Kochavi, pp. 92-149 (in Hebrew).

D. C. B a ramki, Excavations at New Testament Jericho and Khirbet en-Nitle, in AASOR 29-30 (1949-1951), pp. 50-52.

D. J. Chitty, The Desert a City, An Introduction to the Study of Egyptian and Palestinian Monasticism under the Christian Empire, Oxford 1966.

P. V. Corbo, Gli scavi di Kh. Siyar el-Ghanam (Campo dei Pastori) e i monasteri dei Dintorni Gerusalemme, 1955.

P. V. Corbo, L'ambiente materiale della vitta de monaci di Palestina nel periodo byzantino, in OCA 153 (1958), pp. 235-257.

P. V. Corbo, Il cenobio di Zannos e il piccolo cenobio della grande laura ritrovati nel Wadi el-Nar, in La Terra Santa 34 (1958), pp. 107-110.

C. Da uphin, A Farm-Monastery from the Early Byzantine Period at Shelomi, in Qadmoniot 12 (1979), pp. 25-29 (in Hebrew).

R. P. Federlin, Recherches sur les lauras et monastères de la plaine de Jordain et du désert de Jerusalem, in Terre Sainte 19 (1902); 20 (1903); 21 (1904).

I. Finkelstein, Byzantine Monastic Remains in the Southern Sinai, in DOP 39 (1985), pp. 39-75.

G. M. Fitzgerald, A Sixth Century Monastery at Beth-Shan (Skythopolis), IV, Philadelphia 1939.

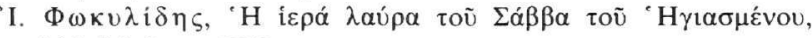

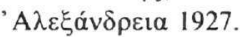

G. H. Forsyth, The Monastery of St. Catherine of Mount Sinai: The Church and Fortress of Justinian, in DOP 22 (1968), pp. 3-18.

Y. Hirschfeld, The Judaean Desert Monasteries in the Byzantine Period, Their Development and Internal Organisation in the Light of Archaeological Research, I-II (Thesis submitted for the Degree Doctor of Philosophy), Jerusalem 1987 (in Hebrew).

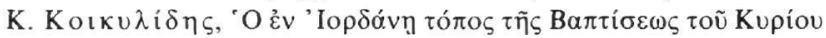

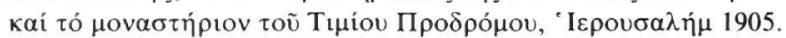

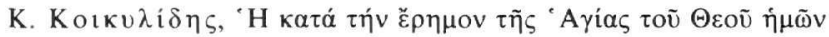

the new sovereign political power. However, from the middle of the 8th century onwards conditions worsened leaving no place for normal monastic life, at least in the countryside or in the desert regions. The monasteries were abandoned one after the other, the once flourishing monachism declined and gradually disappeared. Then, something curious happened. The remnants of monachism returned to urban centres and were enclosed in the aforementioned city branch-monasteries, putting themselves under the control of the institutionalised church authorities. These monastery dependencies, which previously were reception-like centres or catered to the needs of the great mother-monasteries of the desert, have become ever since the only type of the monastery prevailing in the Holyland.

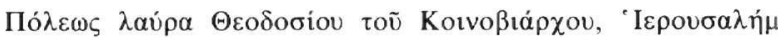
1901.

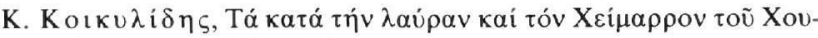
$\zeta ı \tilde{\alpha},{ }^{\prime} I \varepsilon \rho 0 v \sigma \alpha \lambda \eta \dot{\mu} 1901$.

H. M. Liguri, Pagine sparse di monachismo palestinese, in La Terra Santa 16 (1936), pp. $1-3$; 33-39; 79-82; 108-114; 130-137; 163-168; 193-198; 227-232; 280-294; 324-329; 335-361.

Y. Magen, The Monastery of St. Martyrios at Ma'ale Adumim, in Qadmoniot XVIII (1985), pp. 62-92 (in Hebrew).

S. Man, The Magna Laura or the Monastery of Mar Saba, in Christian News from Israel 20 (1969), pp. 64-68.

Y. E. Meimaris, The Hermitage of St. John the Chozebite, Deir Wadi el-Quilt, in Liber Annus 28 (1978), pp. 171-192.

O. Meinardus, Notes on the Laurae and Monasteries of the Wilderness of Judaea, in Liber Annus 15 (1964-1965), pp. 220-250; 16 (1965-1966), pp. 328-356; 19 (1969), pp. 305-327.

O. Meinardus, Wall-Paintings in the Monastic Churches of Judaea, in Orientalia Suecana 50 (1966), pp. 46-55.

J. T. Milik, The Monastery of Kastellion, in Biblica 42 (1961), pp. 21-27.

A. Negev, Cities in the Desert, Tel-Aviv 1966 (in Hebrew).

A. Negev, The Churches of the Central Negev, An Archaeological Survey, in Revue Biblique 81 (1974), pp. 400-492.

A. Ovadia, Corpus of the Byzantine Churches in the Holyland, Bonn 1970.

J. Patrich, Les grottes de el Aleilyat et la laure de Saint Firmin des réfugiés juifs et byzantins, in RBibl 91 (1984), pp. 384-387.

J. Rubin, Monasteries of Ascetics in the Judean Desert in the Byzantine Period, Jerusalem 1980 (Thesis submitted for the Degree Doctor of Philosophy) (in Hebrew).

Y. Tsafrir, Monks and Monasteries in South Sinai, in Qadmoniot 3 (1970), pp. 2-18 (in Hebrew).

V. Tsafrir, Monasticism at Mount Sinai, in Ariel 28 (1971), pp. 65-78.

V. Tzaferis, The Archaeological Excavations at Shepherd's Field, in Liber Annus 25 (1975), pp. 2-52.

V. Tzaferis, The Excavations of Kursi Gergesa, Atigot 16, Jerusalem 1983.

Van der Hayden, Monasteries of the Judean Desert, in Ariel 65 (1986), pp. 77-90.

S. Vailhe, Répertoire alphabétique des monastères de Palestine, in ROChr 4 (1889), pp. 512-542; 5 (1900), pp. 19-48, 272-292. 